\title{
Effect of Irrigation Methods and Nitrogen Application Rates on Yield and Yield Components of Onion (Allium Cepa L.) Grown under Russian Environmental Conditions
}

\author{
Ashraf E. Elnamas
}

\begin{abstract}
Field experiments were conducted to study the influence of three irrigation methods and nitrogen fertilization rates on yield and yield components of onion (Allium Cepa L., cv. Creole Red) grown under Russian environmental conditions during the growing seasons of 2012 and 2013. The three applied irrigation methods were the rain fed (RF), surface drip irrigation (SDI) and subsurface drip irrigation (SSDI) in which placement depths of drip laterals were $10 \mathrm{~cm}$. Nitrogen fertilizer, as ammonium sulfate, was applied at three rates of 0,90 and $180 \mathrm{~kg} \mathrm{~N} \cdot \mathrm{ha}^{-1}$. The experiment was implemented in a randomized complete block design with three replicates. Plant height, number of leaves/plant, Bulb dry matter, bulb diameter and bulb weight of onion (yield components) were measured and consequently crop yield and water use efficiency (WUE) were determined for all treatments. The obtained results indicated that surface drip irrigation or subsurface drip irrigation with $90 \mathrm{~kg}$ $\mathrm{N} / \mathrm{ha}$ resulted in higher yield and yield components. The highest values of plant height, number of leaves/plant, and neck diameter were obtained by SDI $+90 \mathrm{~kg} \mathrm{~N} / \mathrm{ha}$ treatment while the lowest values belonged to $R F$ treatment with zero $(0.0)$ rate of Nitrogen. The fresh crop yield was the highest $\left(38.0 \mathrm{t} \mathrm{ha}^{-1}\right)$ with SDI $+90 \mathrm{~kg} \mathrm{~N} / \mathrm{ha}$ treatment, while $\mathrm{RF}$ treatment with 0.0 nitrogen produced the lowest value of crop yields $\left(20.5 \mathrm{t}\right.$. $\left.\mathrm{ha}^{-1}\right)$. The highest WUE $\left(0.89 \mathrm{t}\right.$. $\left.\mathrm{ha}^{-1} \mathrm{~cm}^{-1}\right)$ was obtained by the SDI $+90 \mathrm{~kg}$ N.ha-1 treatment while the lowest value of WUE was obtained through RF treatment with 0.0 nitrogen. It can be concluded that SDI $+90 \mathrm{~kg} \mathrm{~N} \cdot \mathrm{ha}^{-1}$ treatment was found to be the most effective irrigation method and nitrogen application rate in improving WUE and increasing the yield and yield components of onion grown under Russian environmental conditions.
\end{abstract}

KeyWords: Surface Drip Irrigation, Subsurface Drip Irrigation, Water Use Efficiency, Onion Yield, Nitrogen Fertilization.

\section{INTRODUCTION}

Concerning the production volume and importance, onion is often considered as a major horticultural crop in many countries. Onion (Allium cepa L.) is an important vegetable crop in Russia for exportation and local consummation. A high quality onion can be achieved by increasing the cultivated area and/or increasing the productivity per unit area. Increasing the productivity of onion can be attained by application of the best agricultural practices; e.g., irrigation, fertilization, tillage, pests and diseases control management... etc.

Subsurface drip irrigation system has been considered a part of drip irrigation development in USA since 1960. However, research that imposed SSDI was started since early 1980s. Subsurface drip system is a comparatively new method of irrigation in Russia , arid and semiarid regions of the world. In subsurface drip irrigation system, inline drippers are placed below the ground surface to conserve water, control weeds, and minimize runoff (Longo and Spears 2003). Ayers et al. (1999) summarized 15 years of research conducted on row crops in California USDA-ARS; observing the significant amount of water can be saved using the subsurface drip irrigation. It was found that when crops were irrigated by subsurface drip irrigation, yields were equal to or greater than those obtained by surface drip (Strange Michelle 2005; Singh et al. 2006)

Ells et al., (1993) showed that onion grown under furrow irrigation system requires $1040 \mathrm{~mm}$ of water to achieve a $59 \mathrm{t} \mathrm{ha}^{-1}$ yield in Arkansas River Valley of Colorado. Al-Moshileh (2003) reported that soil water quantity improved plant growth parameters and total yield while marketable yield was reduced. Onion grown under water deficiency decreased in its evapotranspiration and consequently yield (Sammis et al., 2000). Olalla et al. (2004), using drip irrigation experiment, found that the lower volume of water received, the higher the efficiency obtained. They also reported that onion irrigation requirements being in the region of $6000 \mathrm{~m}^{3} / \mathrm{h}^{-1}$. In Spain. Lack of use of optimum fertilizer dose may be a major constraint for maximum onion yield (Shamima and Hossain, 2000).

The interaction of irrigation water and $\mathrm{N}$ significantly affected all plant growth parameters except the number of bulbs and $\mathrm{N}$ uptake of shallot (Jamal K. Fura, 2014).Three different irrigation levels of 60,80 and $100 \%$ of the crop evapotranspiration and six placement depths of the drip laterals $(0,5,10,15$, 20 and $30 \mathrm{~cm}$ ) were maintained in the study. Onion yield was significantly affected by the placement depth of the drip lateral. Maximum yield $\left(25.7 \mathrm{t} \mathrm{ha}^{-1}\right)$ was obtained by applying $60.7 \mathrm{~cm}$ of irrigation water and by placing the drip lateral at $10 \mathrm{~cm}$ soil depth.

DOI: 10.21608/ASEJAIQJSAE.2019.53810

${ }^{1}$ Department of Soil and Water Science, Faculty of Agric., Alexandria University

Received September 02, 2019, Accepted September 30, 2019 
Maximum irrigation water use efficiency (IWUE) of $0.55 \mathrm{t} \mathrm{ha}^{-1} \mathrm{~cm}^{-1}$ was obtained by placing the drip lateral at $10 \mathrm{~cm}$ depth (Rajput and Patel, 2009). Irrigation water use efficiency (IWUE) and $\mathrm{N}$ use efficiency (NUE) were higher with drip irrigation than with the furrow irrigation ( Halvorson et al.,2008).

The objective of this study was to determine the effect of irrigation methods and nitrogen application rates on yield, plant height, number of leaves/plant, Bulb dry matter, bulb diameter and bulb weight of onion (yield components) and water use efficiency (WUE) of plant crop.

\section{MATERIALS AND METHODS}

\section{Climate and Soil Characteristics:}

The field experiment was conducted at the Experimental Farm, southeast Moscow city - Russia, during the growing seasons; May - August 2012 and 2013. The geographical position is located at latitude $55^{\circ} 75^{\prime \prime} \mathrm{N}$, and longitude $37^{\circ} 61^{\prime \prime} \mathrm{E}$ with an elevation of $151 \mathrm{~m}$ above the mean sea level. The meteorological data during the two growing seasons are shown in Figs.1-8. The precipitations were 365.5 and $340 \mathrm{~mm}$. during the two growing seasons ; 2012 and 2013, respectively. The values of relative humidity during daytime were $67.3 \%$ and $78.6 \%$ in the two growing seasons, respectively. The average temperature in 2013 was higher than in 2012, with values of 17, 21.1, 20 and $18^{\circ} \mathrm{C}$ in 2013 , and $14.5,11.6,19.2$ and $18.6^{\circ} \mathrm{C}$ in 2012, during May - August of each.

The soil chemical and physical properties were determined as follows: the $\mathrm{pH}$ was measured in 1:2.5 soil water suspension and the electrical conductivity (EC) was measured in the saturated soil-paste extract (Richard, 1954); organic matter by dichromate oxidation method (Nelson and Sommers, 1982); cation exchange capacity (CEC) by IM NaOAc method (Rhoades, 1982); particle size distribution by the hydrometer method (Day, 1965); total calcium carbonate by a calcimeter method (Nelson, 1982); available $\mathrm{P}$ by $0.5 \mathrm{M} \mathrm{NaHCO}_{3}$ of $\mathrm{pH} 8.5$ (Olsen and Sommers, 1982); available nitrogen by $2 \mathrm{M} \mathrm{KCl}$ method (Bremner and Mulvancy, 1982); available potassium by IN ammonium acetate of pH 7.0 method (Knudsen and Peterson, 1982); and the bulk density by cold method (Tan, 1996). The soil physical and chemical properties are presented in Table (1). The source of irrigation water was fresh water canal and its chemical analysis shown in table 2 .

\section{Experimental Layout:}

Field experiments were conducted to study the influence of three irrigation methods and nitrogen fertilization levels on yield and yield components of onion (Allium Cepa L., cv. Creole Red) under conditions of Russia environment, during the growing seasons; May - August 2012 and 2013. The three applied irrigation methods were the rainfall (RF), surface drip irrigation (SDI) and subsurface drip irrigation (SSDI) in which placement depths of the drip lateral was $10 \mathrm{~cm}$ below the ground surface. Nitrogen fertilizer as ammonium sulfate $(21 \% \mathrm{~N})$ was applied in three rates of $0,90,180 \mathrm{~kg} \mathrm{~N} \cdot \mathrm{ha}^{-1}$. The overall treatments were :-

$$
\begin{aligned}
& \text { i. } \mathrm{I}_{1} \mathrm{~N}_{\mathrm{o}} \text { : }\left(\mathrm{RF} \mathrm{N}_{0}\right) \text { the rain fed }+0 \mathrm{~kg} \mathrm{~N} \cdot \mathrm{ha}^{-1} \\
& \text { ii. } \mathrm{I}_{1} \mathrm{~N}_{1}:\left(\mathrm{RF} \mathrm{N}_{90}\right) \text { the rain fed }+90 \mathrm{~kg} \mathrm{~N} \cdot \mathrm{ha}^{-1} \\
& \text { iii. } \mathrm{I}_{1} \mathrm{~N}_{2} \text { : }\left(\mathrm{RF} \mathrm{N}_{180}\right) \text { the rain fed }+180 \mathrm{~kg} \mathrm{~N} \cdot \mathrm{ha}^{-1} \\
& \text { iv. } \mathrm{I}_{2} \mathrm{No} \text { : }\left(\mathrm{SDI} \mathrm{N}_{0} \text { )surface drip irrigation }+0 \mathrm{~kg}\right.
\end{aligned}
$$
N.ha $a^{-1}$ N.ha ${ }^{-1}$ N.ha $\mathrm{a}^{-1}$

vii. $\mathrm{I}_{3} \mathrm{~N}_{\mathrm{o}}$ : ( SSDI $\left.\mathrm{N}_{0}\right)$ subsurface drip irrigation +0 $\mathrm{kg} \mathrm{N} \cdot \mathrm{ha}^{-1}$

viii. $\mathrm{I}_{3} \mathrm{~N}_{1}:\left(\mathrm{SSDI} \mathrm{N}_{90}\right)$ subsurface drip irrigation +90 kg N.ha ${ }^{-1}$

ix. $\mathrm{I}_{3} \mathrm{~N}_{2}$ : ( $\mathrm{SSDI} \mathrm{N}_{180}$ ) subsurface drip irrigation + $180 \mathrm{~kg} \mathrm{~N} \cdot \mathrm{ha}^{-1}$

Onion seedlings were transplanted to the plots (18 May 2012). The plants were grown $0.20 \mathrm{~m}$ apart between the rows with $0.10 \mathrm{~m}$ spacing in each row. Each plot has contained 600 plants. In order to overcome the water movement in any one plot, from affecting its neighboring plots, only 50 plants of middle row were harvested.

Bulb length $(\mathrm{cm})$, leaf number per plant, bulb diameter $(\mathrm{cm})$, and bulb weight $(\mathrm{g})$ were measured by caliper rule and calculated as the average of measured values. The dry matter was obtained after drying at $85^{\circ} \mathrm{C}$ for 48 hours. Nitrogen content in bulb was determined by modified Kjeldahl digestion method (Yamakawa, 1993).

The layout of the field experiment was a completely randomized block design with three replications for each of the three method irrigation treatments. However, replications have been distributed to the random blocks in such a way that following same range in three blocks not to disturb the existing irrigation system. 

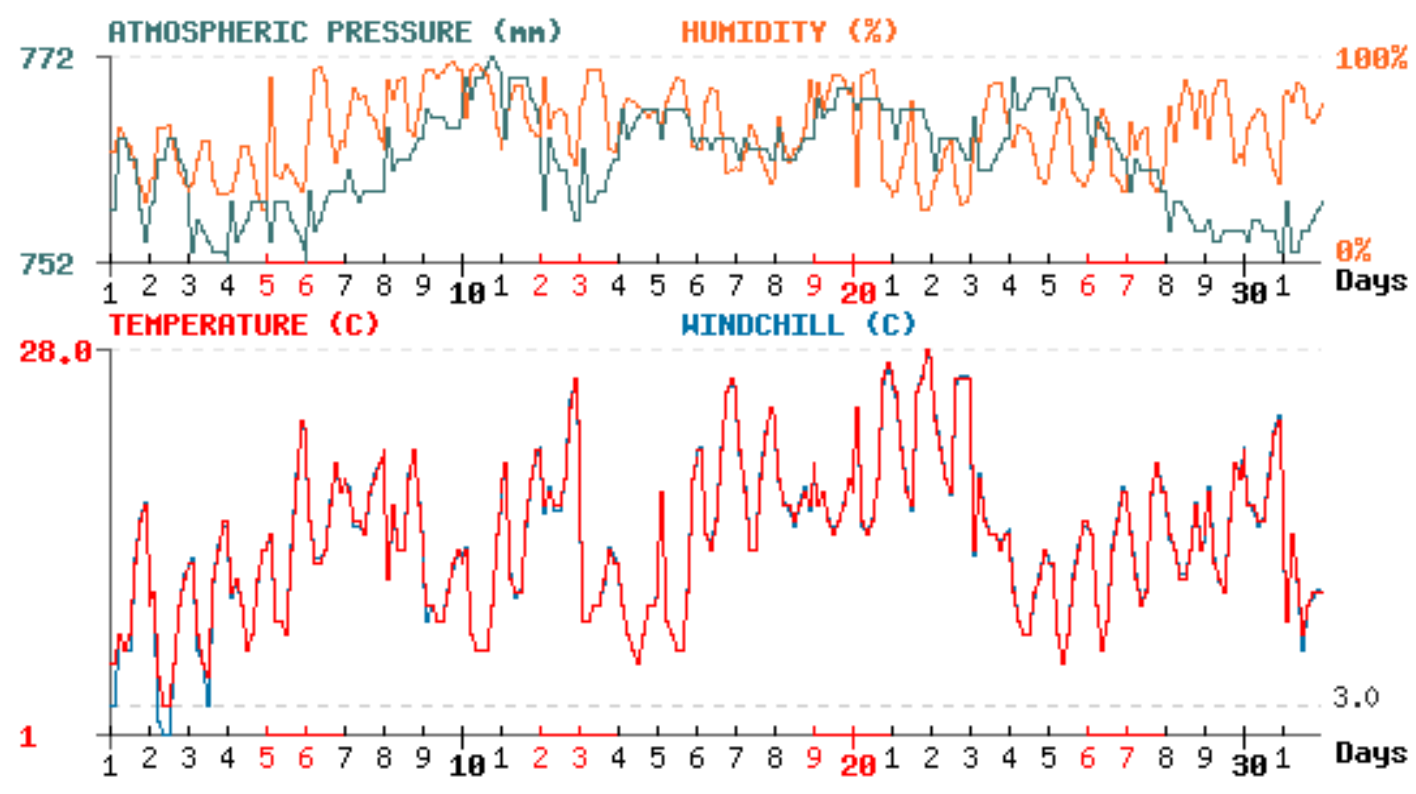

May 2012

Meather in Moscow, RU - Conpiled by FlyMig,Con

Fig. 1. Meteorological data during May 2012
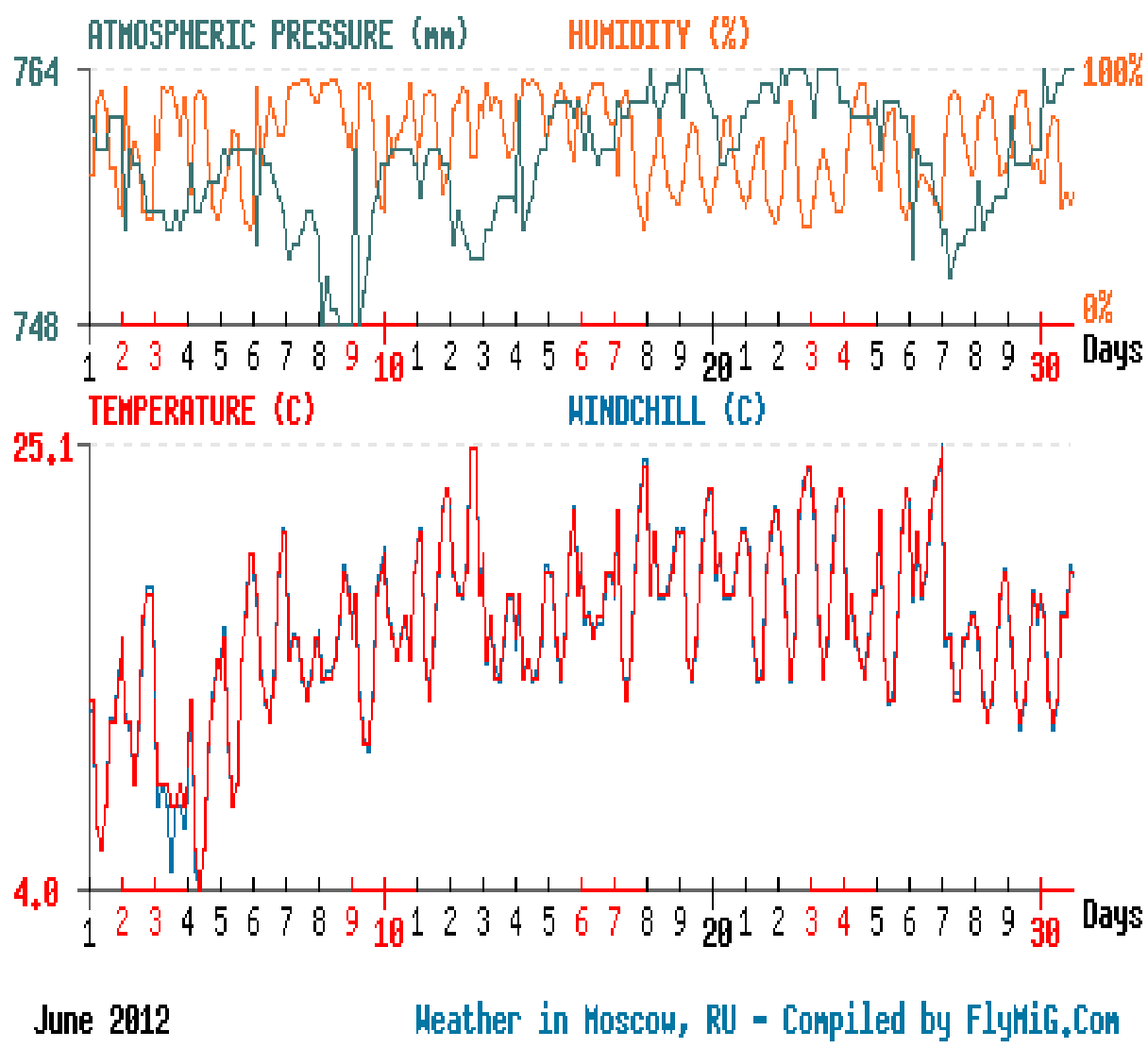

Fig.2. Meteorological data during June 2012 


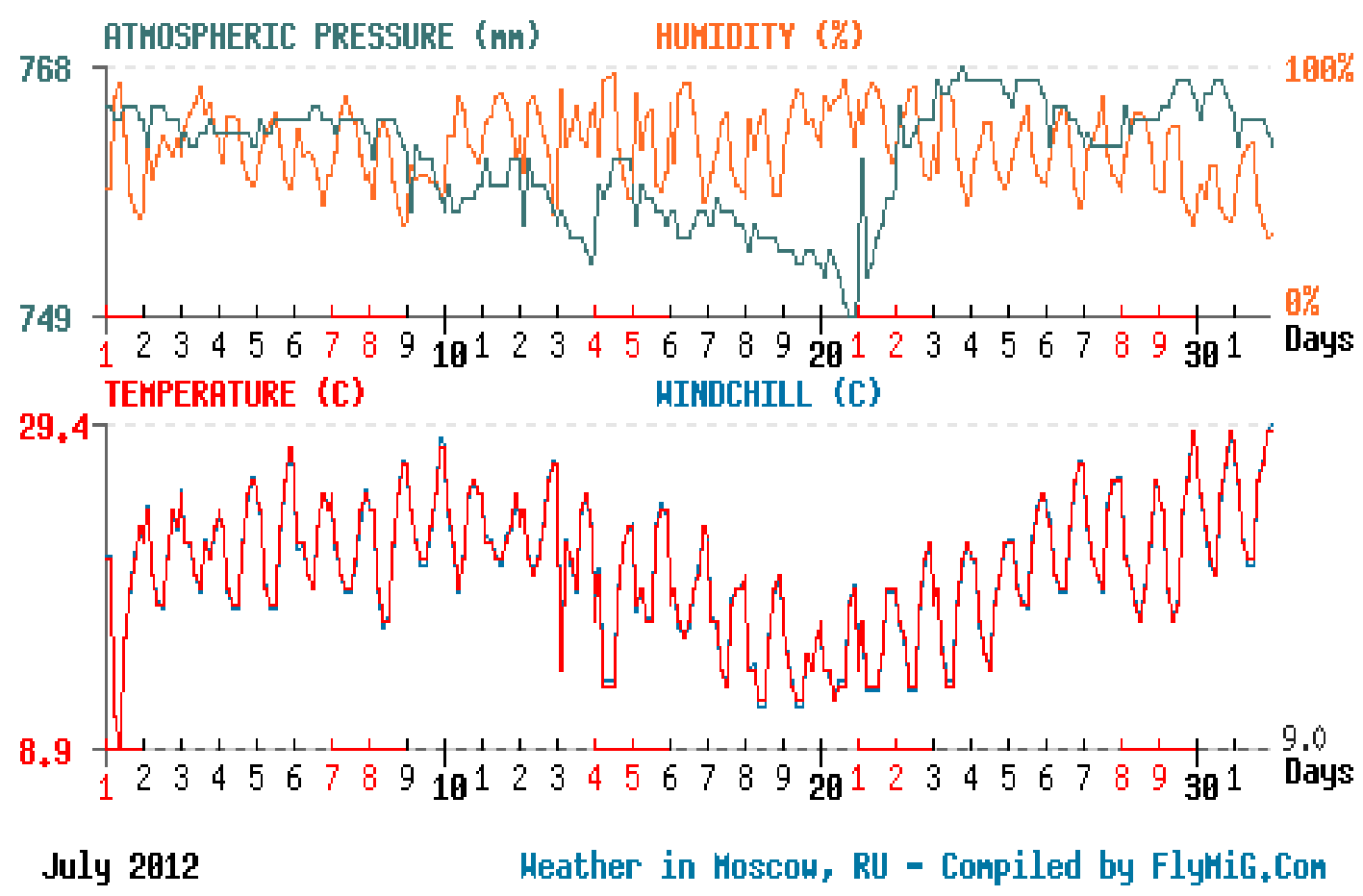

Fig. 3. Meteorological data during July 2012
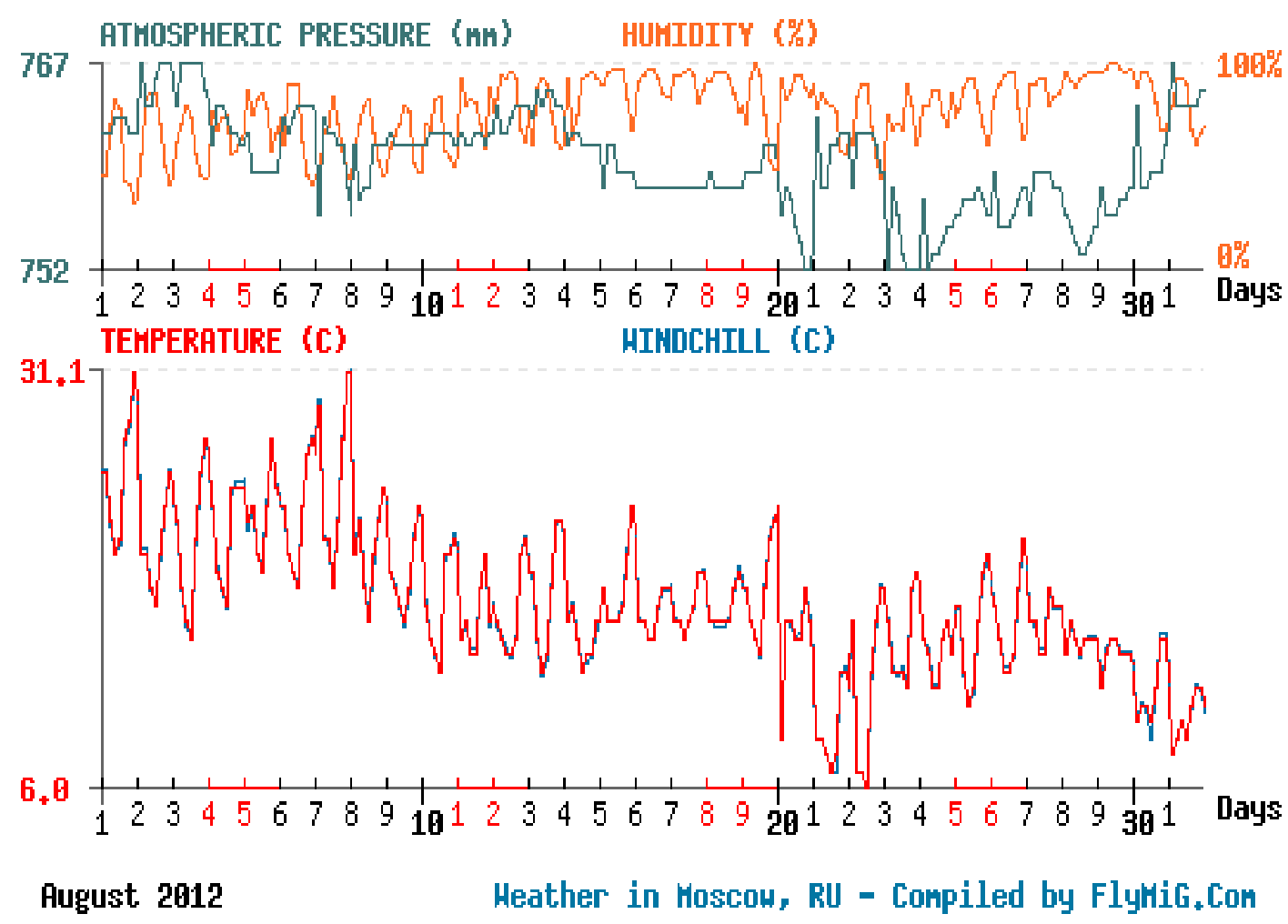

Fig. 4. Meteorological data during August 2012 


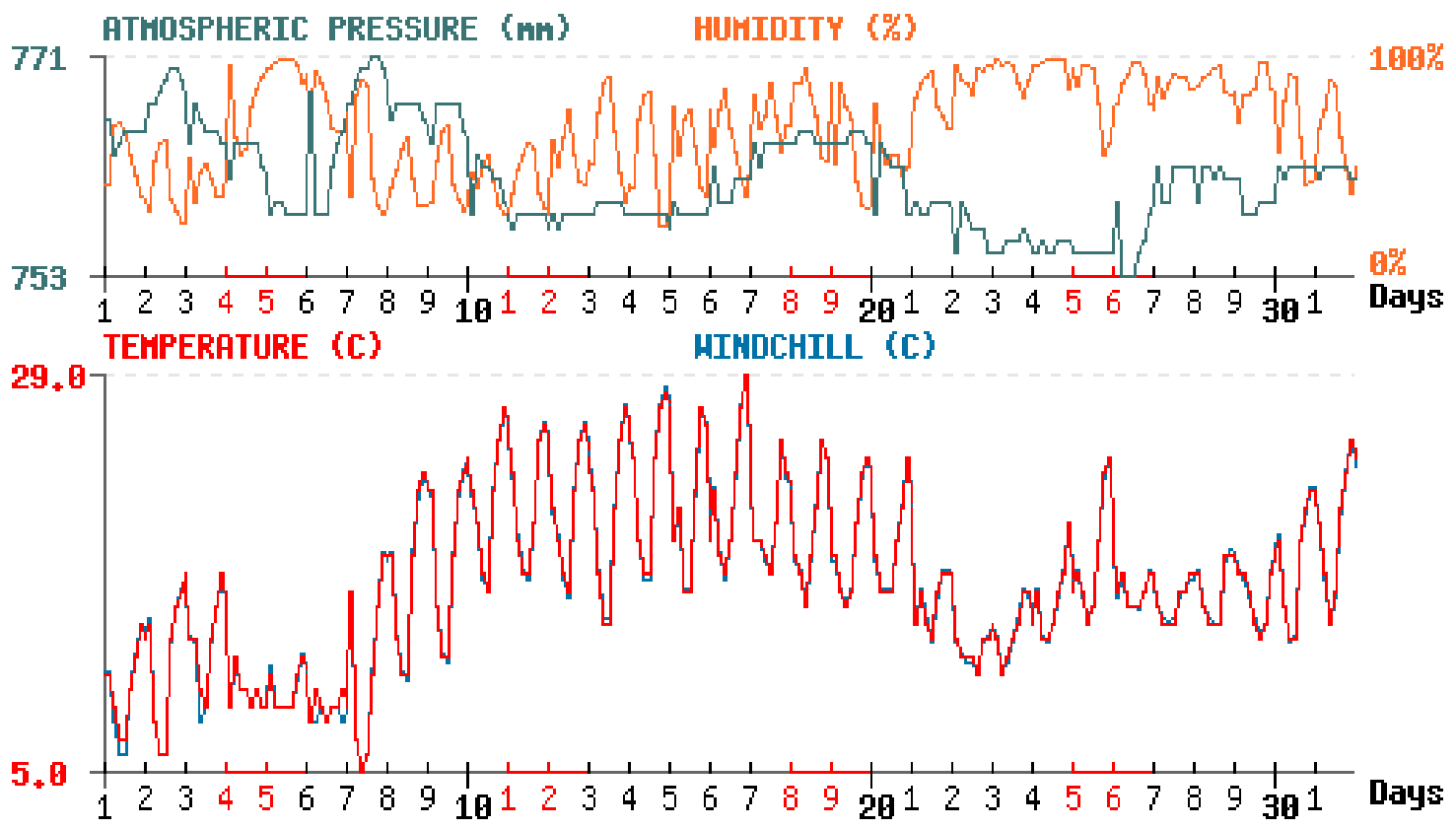

May 2013 Heather in Moscow, RU - Conpiled by FlyMig,Con

Fig. 5. Meteorological data during May 2013
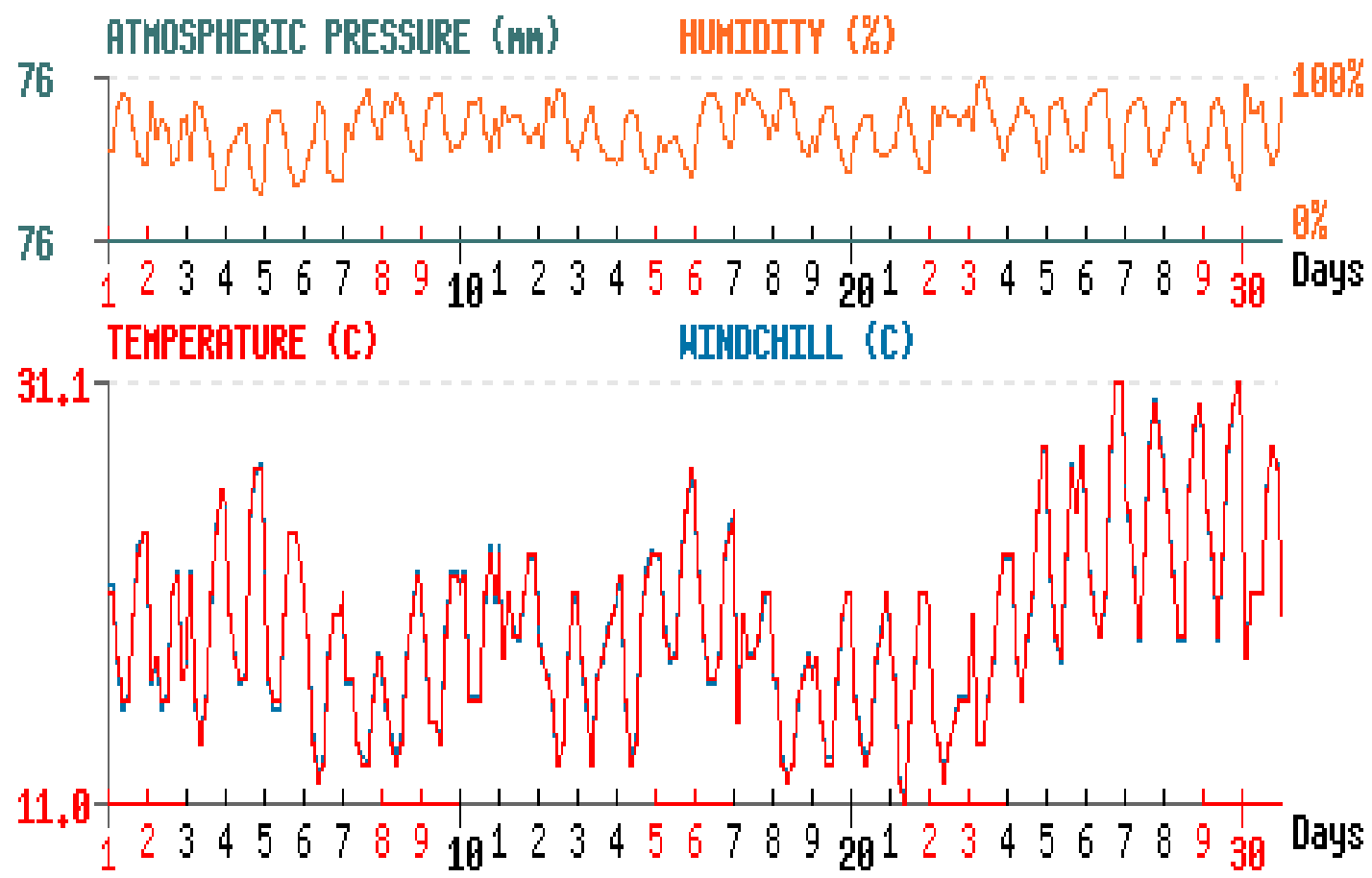

PERTL (C) HIHDCHILL (C)

June 2013

$$
\text { Heather in Hoscou, RU - Conpiled by Flytilí, Con }
$$

Fig. 6. Meteorological data during June 2013 

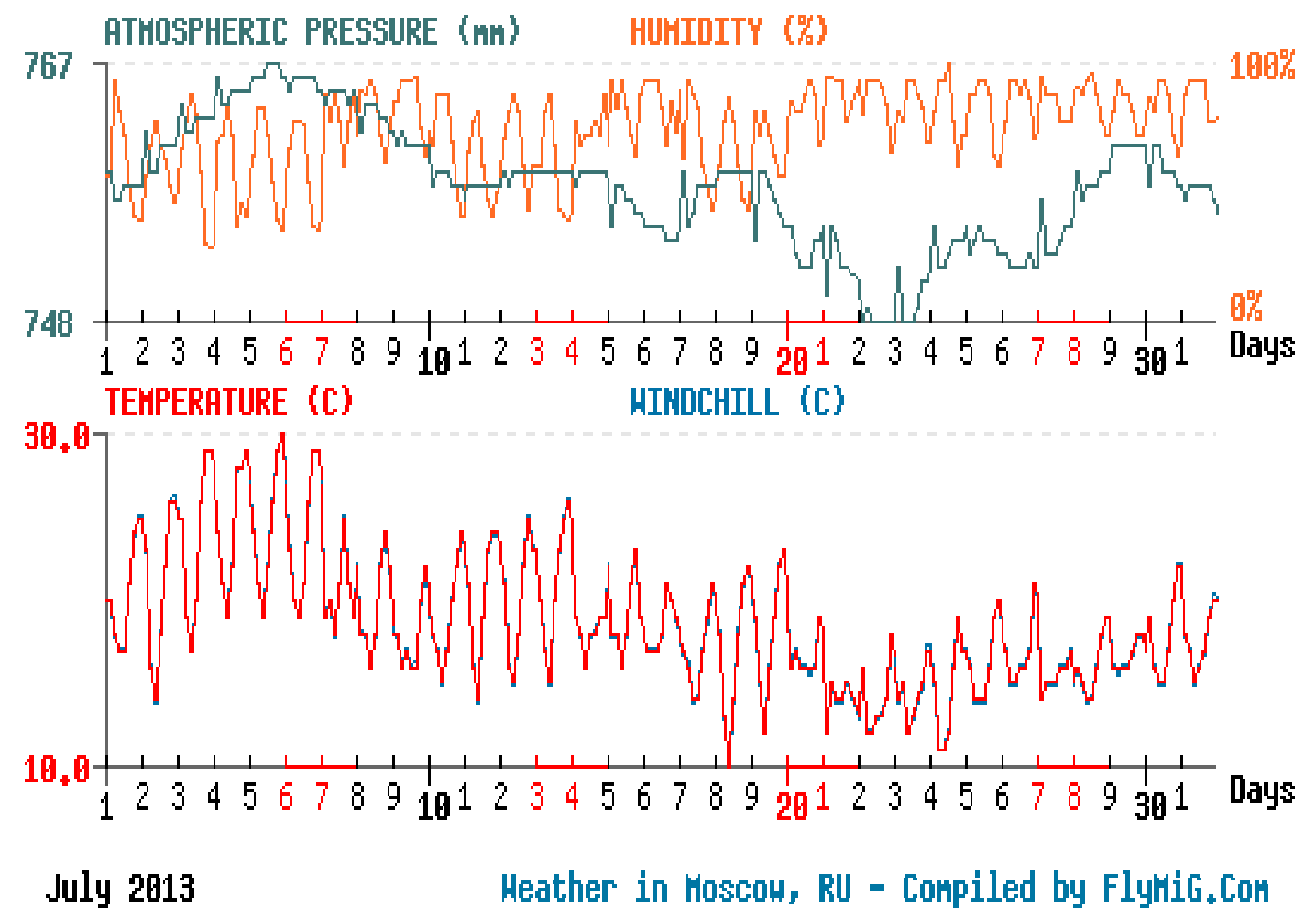

Fig. 7. Meteorological data during July 2013
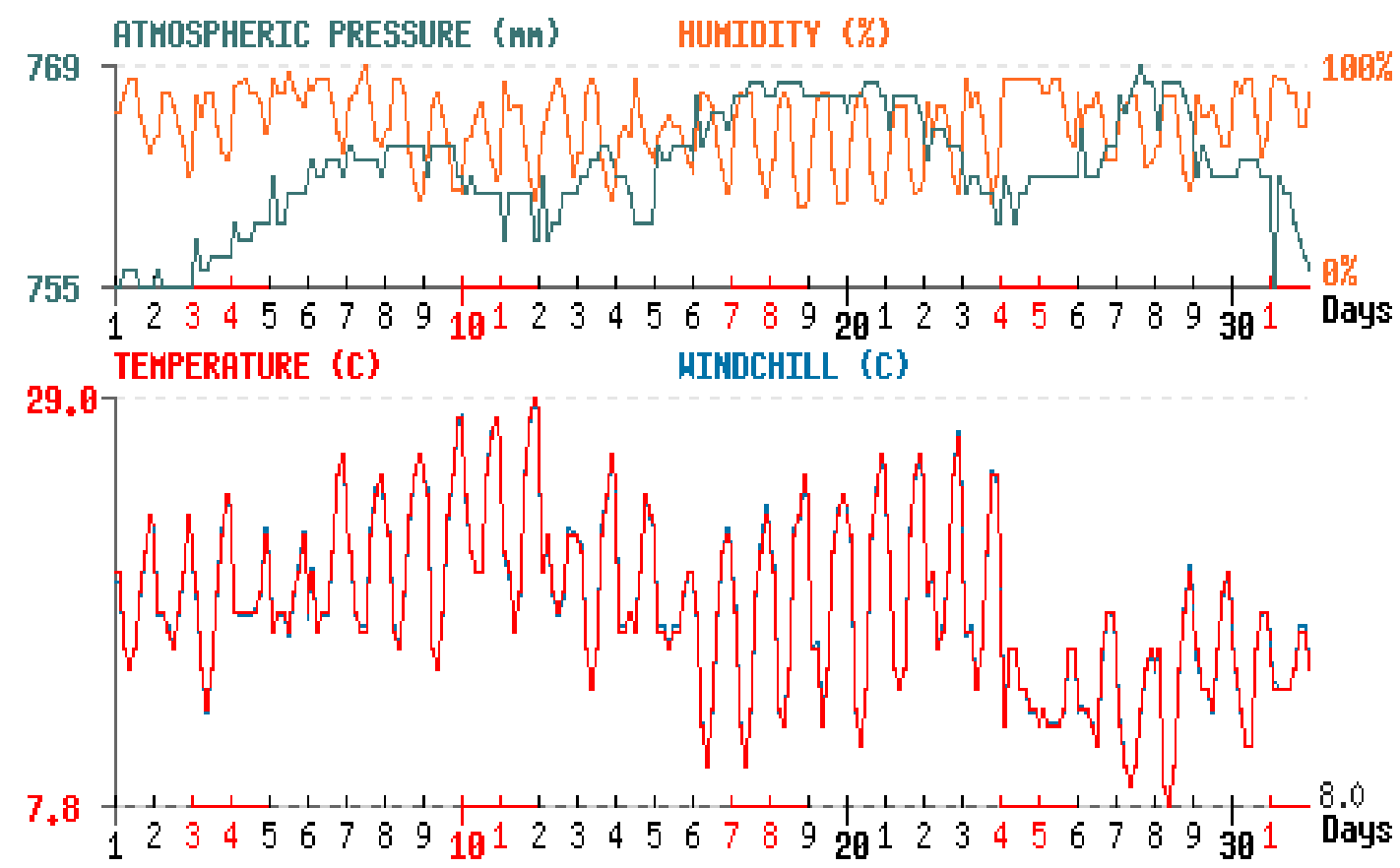

August 2013

Heather in Moscon, RU - Conpiled by FlyHig,Con

Fig.8. Meteorological data during August 2013 
Table 1. The main physical and chemical properties of the experimental Soil a

\begin{tabular}{ccc}
\hline Soil characteristics & Unit & Value \\
\hline Particle size distribution: & $\mathrm{g} \mathrm{kg}^{-1}$ & \\
Sand & $\mathrm{g} \mathrm{kg}^{-1}$ & $429.00 \pm 5.29$ \\
Silt & $\mathrm{g} \mathrm{kg}^{-1}$ & $330.54 \pm 2.52$ \\
Clay & & $240.46 \pm 4.69$ \\
Soil texture & $\mathrm{Kg}^{-3}$ & Loam \\
$\mathrm{D}_{\mathrm{b}}$ & $\mathrm{dSm}^{-1}$ & $1360 \pm 11.00$ \\
EC & & $1.87 \pm 0.12$ \\
pH(range) & $\mathrm{g} \mathrm{kg}^{-1}$ & $7.70-8.08$ \\
Total CaCO & $\mathrm{g} \mathrm{kg}^{-1}$ & $61.04 \pm 3.56$ \\
O.M. & ${\mathrm{Cmo}(+) \mathrm{kg}^{-1}}^{-}$ & $20.41 \pm 0.86$ \\
CEC & $\mathrm{g} \mathrm{kg}^{-1}$ & $27.84 \pm 3.69$ \\
Olsen-P & $\mathrm{g} \mathrm{kg}^{-1}$ & $10.55 \pm 0.43$ \\
Available-N & $\mathrm{g} \mathrm{kg}^{-1}$ & $14.24 \pm 0.89$ \\
Available-K & & $132.85 \pm 6.43$ \\
\hline
\end{tabular}

a Data represent the mean \pm standard deviation, expect for $\mathrm{pH}$.

Table 2. The chemical analysis of the irrigation waters used in the study (means \pm SD except for $\mathbf{p H}$ )

\begin{tabular}{|c|c|c|c|c|c|c|c|c|}
\hline \multirow{2}{*}{$\begin{array}{l}\text { Sources } \\
\text { Irrigation } \\
\text { Water }\end{array}$} & \multirow{2}{*}{$\begin{array}{r}E C \\
d_{S m^{-1}}\end{array}$} & \multirow[t]{2}{*}{ pH } & $\mathrm{Cl}^{-1}$ & $\mathrm{Na}^{+1}$ & $\mathrm{Ca}^{+2}$ & $\mathrm{Mg}^{+2}$ & $\mathrm{HCO}_{3}^{-1}$ & \multirow[t]{2}{*}{ SAR } \\
\hline & & & & & meql $^{-1}$ & & & \\
\hline Canal $^{\mathrm{a}}$ & $0.62 \pm 0.05$ & 7.19 & $2.30 \pm 0.73$ & $2.78 \pm 0.10$ & $1.09 \pm 0.050$ & $0.52 \pm 0.03$ & $4.20 \pm 0.20$ & $3.12 \pm 0.18$ \\
\hline $\mathrm{IWC}^{\mathrm{b}}$ & 3.00 & $6.50-9.00$ & 10.00 & 3.00 & 20.00 & 5.00 & 1.50 & $6-12$ \\
\hline
\end{tabular}

${ }^{\mathrm{a}}$ Means of three samples $\pm \mathrm{SD}$,

bIWC: Irrigation water criteria, US EPA 1992.

\section{Crop Water - Use Parameters:}

\section{1-Applied water:}

Pan evaporation method was used for calculating the amount of applied water as follows:

$$
\mathrm{IW}=\mathrm{E}_{\mathrm{pan}} \mathrm{x} \mathrm{K}_{\mathrm{cp}}
$$

Where; IW is the amount of applied irrigation water $(\mathrm{mm}), \mathrm{E}_{\mathrm{pan}}$ the cumulative evaporation between each irrigation interval $(\mathrm{mm})$ and $\mathrm{K}_{\mathrm{cp}}$ is the plant-pan coefficient.

Crop evapotranspiration $\left(\mathrm{ET}_{\mathrm{c}}\right)$ was estimated using the following form of the water balance equation:

$$
\mathrm{ET}_{\mathrm{c}}=\left(\mathrm{SWC}_{10}-\mathrm{SWC}_{11}\right)+\mathrm{IW}-\mathrm{D}
$$

Where; $\left(\mathrm{SWC}_{10}-\mathrm{SWC}_{11}\right)$ is the change in volumetric soil water content between two measurement dates, IW and D are respectively the total volumes of applied irrigation water and collected drainage water for the period under consideration.

The water content of plant root depth $(0.60 \mathrm{~m})$ was determined by gravimetric method before application of irrigation water (Lorenz, O.A. and Maynard, D.N. 1980) and monitored in $30 \mathrm{~cm}$ depth increments to $0.90 \mathrm{~m}$ after irrigation for each irrigation treatments. Monitoring soil water content in the plots revealed that deep percolation below $0.60 \mathrm{~m}$ depth was negligible.

\section{2- Water consumptive use:}

Gravimetric soil samples, from soil surface down to $0.45 \mathrm{~m}$ depth at $0.15 \mathrm{~m}$ intervals, were collected from all treatments after seeding, before and after each irrigation, and at harvest time to determine water consumptive use $(\mathrm{Cu})$ or as considered equal to actual evapotranspiration $\left(\mathrm{Et}_{\mathrm{a}}\right)$. Consumptive use was calculated according to Israelsen and Hansen (1962) as follows:

$$
\mathrm{CU}=\sum_{i=1}^{n} \frac{\left.\left(\theta_{2}-\theta_{1}\right)\right)}{100} \times \frac{\int b}{\int w} \times \mathrm{D}
$$

Where:

$\mathrm{CU}=$ water consumptive use $(\mathrm{mm})$

$\theta_{2}=$ soil moisture content after an irrigation event $\left(\mathrm{kg} \mathrm{kg}^{-1}\right)$.

$\theta_{1}=$ soil moisture content just before the next irrigation event $\left(\mathrm{kg} \mathrm{kg}^{-1}\right)$.

$$
\begin{aligned}
& \int_{\mathrm{w}}=\text { water density }\left(\mathrm{Kg} / \mathrm{m}^{3}\right) . \\
& \mathrm{D}=\text { depth of soil layer }(\mathrm{cm}) . \\
& \mathrm{b} \quad=\text { bulk density }\left(\mathrm{Kg} / \mathrm{m}^{3}\right) \\
& \mathrm{i} \quad=\text { soil layers }(1,2, \ldots \ldots \mathrm{n})
\end{aligned}
$$

\section{3-Water use efficiency (WUE)}

The values of water use efficiency $\left(\mathrm{kg}\right.$ per $\mathrm{m}^{3}$ of water consumed) values were calculated according to Jensen (1983) as follows: 


$$
\text { WUE }=\frac{\text { Onion yield }(\mathrm{Kg} / \mathrm{ha})}{\text { Consumed Irrigation water }\left(\mathrm{m}^{3} / \mathrm{ha}\right)}
$$

\section{4- Statistical Analysis:}

The obtained data were statistically analyzed using the COSTAT Software (Cohort, 1986) statistical package. Average values from the three replicates of each treatment were interpreted using the analysis of variance (ANOVA).

\section{RESULTS AND DISCUSSION}

\section{1-Soil and Water Characteristics}

The texture of the experimental soil was loam soil having particle size distribution of $429 \mathrm{~g} \mathrm{~kg}^{-1}$ sand, $330.5 \mathrm{~g} \mathrm{~kg}^{-1}$ silt and $240.5 \mathrm{~g} \mathrm{~kg}^{-1}$ clay at soil depth of 0 $-20 \mathrm{~cm}$. with medium total carbonate $\left(61 \mathrm{~g} \mathrm{~kg}^{-1}\right)$ and organic matter $(20.41 \mathrm{~g} / \mathrm{kg})$. Its reaction is slightly alkaline $(\mathrm{pH}=7.70$ to 8.08$)$ which is considered suitable for onion crop production according to Lemma and Shimeles (2003). The soil can be considered containing medium levels of available nitrogen (14.24 $\mathrm{g} / \mathrm{kg})$, available phosphorus $(10.55 \mathrm{~g} / \mathrm{kg})$, EC (1.87 $\mathrm{ds} / \mathrm{m})$ and CEC $\left(27.84\left(\mathrm{cmol}(+) \mathrm{kg}^{-1}\right)\right.$ as suggested by Landon (1991). Implying any crop and soil differences experienced during the experiments may be attributed to the treatments and not to soil heterogeneity. Concerning the physical and the chemical properties (Table 1), this soil is quite suitable for such crop and irrigation system (Živkovic et al., 1972)..

As compared with USEPA (1993) guidelines, concerning maximum allowed irrigation water criteria, the data presented in Table (2), showed that soluble salts, chloride, sodium, bicarbonate and SAR values were less than the US EPA criteria.

\section{2-Growth and Yield Parameters}

\section{1- Plant height}

Table 3.The values of onion growth parameters as affected by irrigation methods and nitrogen application rates at the two growing season 2012 and 2013

\begin{tabular}{|c|c|c|c|c|c|c|c|c|c|c|c|c|c|c|c|}
\hline \multirow[t]{2}{*}{ Treatments } & \multicolumn{3}{|c|}{ Plant height (cm) } & \multicolumn{3}{|c|}{$\begin{array}{c}\text { Number of leaves } \\
\text { per plant }\end{array}$} & \multicolumn{3}{|c|}{ Bulb dry matter (\%) } & \multicolumn{3}{|c|}{ Bulb diameter (cm) } & \multicolumn{3}{|c|}{ Average bulb weight (gm) } \\
\hline & 2012 & 2013 & Mean & 2012 & 2013 & Mean & 2012 & 2013 & Mean & 2012 & 2013 & Mean & 2012 & 2013 & Mean \\
\hline $\mathrm{I}_{1} \mathrm{~N}_{0}$ & $40.1 \mathrm{c}$ & $43.1 \mathrm{c}$ & $41.6 \mathrm{c}$ & $5.3 b$ & $5.4 \mathrm{c}$ & $5.4 \mathrm{~b}$ & $12.6 \mathrm{c}$ & $12.4 \mathrm{~b}$ & $12.5 \mathrm{c}$ & $3.1 \mathrm{c}$ & $3.2 \mathrm{~d}$ & $3.2 \mathrm{~d}$ & $59.2 \mathrm{c}$ & $60.1 \mathrm{c}$ & $59.7 \mathrm{c}$ \\
\hline $\mathrm{I}_{1} \mathrm{~N}_{1}$ & $43.5 b$ & $45.2 \mathrm{c}$ & $44.4 \mathrm{c}$ & $5.7 \mathrm{~b}$ & $6.0 \mathrm{~b}$ & $5.9 \mathrm{~b}$ & $13.4 \mathrm{~b}$ & $13.2 b$ & $13.3 b$ & $4.0 \mathrm{~b}$ & $3.8 \mathrm{c}$ & $3.9 \mathrm{c}$ & $64.3 \mathrm{c}$ & $65.7 \mathrm{c}$ & $65.0 \mathrm{c}$ \\
\hline $\mathrm{I}_{1} \mathrm{~N}_{2}$ & $46.2 b$ & $47.4 \mathrm{c}$ & $46.8 b$ & $5.7 \mathrm{~b}$ & $5.7 \mathrm{~b}$ & $5.7 \mathrm{~b}$ & $12.8 \mathrm{c}$ & $12.6 \mathrm{~b}$ & $12.7 \mathrm{~b}$ & $4.1 \mathrm{~b}$ & $4.1 \mathrm{c}$ & $4.1 \mathrm{c}$ & $70.2 \mathrm{c}$ & $69.5 \mathrm{c}$ & $69.9 \mathrm{c}$ \\
\hline $\mathrm{I}_{2} \mathrm{~N}_{0}$ & $48.2 b$ & $51.2 b$ & $49.7 b$ & $6.1 \mathrm{~b}$ & $6.3 b$ & $6.2 b$ & $13.2 b$ & $13.1 \mathrm{~b}$ & $13.2 b$ & $4.5 b$ & $4.3 \mathrm{c}$ & $4.4 \mathrm{~b}$ & $72.4 \mathrm{~b}$ & $73.8 b$ & $73.1 \mathrm{~b}$ \\
\hline $\mathrm{I}_{2} \mathrm{~N}_{1}$ & $55.6 \mathrm{a}$ & $61.2 \mathrm{a}$ & $58.4 \mathrm{a}$ & $8.2 \mathrm{a}$ & $8.5 \mathrm{a}$ & $8.4 \mathrm{a}$ & $14.8 \mathrm{a}$ & $14.5 \mathrm{a}$ & $14.7 \mathrm{a}$ & $4.7 \mathrm{a}$ & $4.5 b$ & $4.6 \mathrm{~b}$ & $84.7 \mathrm{~b}$ & $85.2 \mathrm{~b}$ & $85.0 \mathrm{~b}$ \\
\hline $\mathrm{I}_{2} \mathrm{~N}_{2}$ & $53.3 \mathrm{a}$ & $56.1 \mathrm{a}$ & $54.7 \mathrm{a}$ & $7.5 \mathrm{a}$ & $8.0 \mathrm{a}$ & $7.8 \mathrm{a}$ & $14.2 \mathrm{a}$ & $14.3 \mathrm{a}$ & $14.3 \mathrm{a}$ & $5.2 \mathrm{a}$ & $5.3 \mathrm{a}$ & $5.3 \mathrm{a}$ & $102.4 \mathrm{a}$ & $101.6 \mathrm{a}$ & $102.0 \mathrm{a}$ \\
\hline $\mathrm{I}_{3} \mathrm{~N}_{0}$ & $47.3 b$ & $49.2 b$ & $48.3 b$ & $6.3 b$ & $6.6 \mathrm{~b}$ & $6.5 b$ & $13.5 b$ & $13.3 \mathrm{a}$ & $13.4 \mathrm{a}$ & $4.1 \mathrm{~b}$ & $4.0 \mathrm{~b}$ & $4.1 \mathrm{~b}$ & $69.4 \mathrm{c}$ & $68.3 \mathrm{c}$ & $68.9 \mathrm{c}$ \\
\hline $\mathrm{I}_{3} \mathrm{~N}_{1}$ & $52.3 \mathrm{a}$ & $53.6 \mathrm{~b}$ & $53.0 \mathrm{a}$ & 7.9a & $8.2 \mathrm{a}$ & $8.1 \mathrm{a}$ & $14.5 \mathrm{a}$ & $14.6 \mathrm{a}$ & $14.6 \mathrm{a}$ & $4.2 b$ & $4.3 b$ & $4.3 b$ & $84.6 \mathrm{~b}$ & $80.4 b$ & $82.5 b$ \\
\hline $\mathrm{I}_{3} \mathrm{~N}_{2}$ & $50.8 \mathrm{a}$ & $52.8 \mathrm{~b}$ & $51.8 \mathrm{~b}$ & $7.3 \mathrm{a}$ & $7.5 \mathrm{a}$ & $7.4 \mathrm{a}$ & $13.9 \mathrm{~b}$ & $14.2 \mathrm{a}$ & $14.1 \mathrm{a}$ & $4.8 \mathrm{a}$ & $4.6 \mathrm{~b}$ & $4.7 \mathrm{a}$ & $90.5 \mathrm{a}$ & $89.7 \mathrm{a}$ & $90.1 \mathrm{a}$ \\
\hline L.S.D. 05 & 4.9 & 5.6 & 5.2 & 1.1 & 1.2 & 1.1 & 0.75 & 0.84 & 0.81 & 0.60 & 0.58 & 0.59 & 13.9 & 13.2 & 13.5 \\
\hline
\end{tabular}

Table 3 showed highly significant difference $(\mathrm{P}<$ $0.05)$ in plant height due to irrigation methods and value of plant height $(58.40 \mathrm{~cm})$ was recorded with surface drip irrigation method fertilized with $90 \mathrm{~N} \mathrm{~kg}$ $\mathrm{ha}^{-1}\left(\mathrm{I}_{2} \mathrm{~N}_{1}\right)$,i.e. SDI $\mathrm{N}_{90}$. However, there was no significant difference as a result of fertilization with 180 $\mathrm{N} \mathrm{kg} \mathrm{ha}{ }^{-1}$ with $\left(\mathrm{I}_{2} \mathrm{~N}_{2}\right)$, i.e. SDI $\mathrm{N}_{180}$ and with $90 \mathrm{~N} \mathrm{~kg} \mathrm{ha}^{-}$ ${ }_{1}^{1}$ with subsurface drip irrigation treatment $\left(\mathrm{I}_{3} \mathrm{~N}_{2}\right)$, i.e. SSDI $\mathrm{N}_{90}$. On the other side, the mean value of the lowest plant height $(40.1 \mathrm{~cm})$ was recorded for plant unfertilized with nitrogen and with no irrigation which is depending on rainfall $\left(\mathrm{I}_{1} \mathrm{~N}_{0}\right)$, i.e. RF $\mathrm{N}_{0}$ treatment. The increase in plant height with increases of nitrogen application rate and using the two irrigation methods soil moisture and sufficient up take of $\mathrm{N}$ which has enhanced the vegetative growth of onion .

The recorded plant height were 40.1, 43.5 , 46.2, $48.2,55.6,53.3,47.3,52.3$ and $50.8 \mathrm{~cm}$ for $\mathrm{I}_{1} \mathrm{~N}_{0}$, $\mathrm{I}_{1} \mathrm{~N}_{1}, \mathrm{I}_{1} \mathrm{~N}_{2}, \mathrm{I}_{2} \mathrm{~N}_{0}, \mathrm{I}_{2} \mathrm{~N}_{1}, \mathrm{I}_{2} \mathrm{~N}_{2}, \mathrm{I}_{3} \mathrm{~N}_{0}, \mathrm{I}_{3} \mathrm{~N}_{1}$ and $\mathrm{I}_{3} \mathrm{~N}_{2}$ treatments, respectively in the growing season 2012 and $43.1,45.2,47.4,51.2,61.2,56.1,49.2,53.6$ and 52.8 for the same treatments, respectively in the growing season 2013 . The markedly higher values of plant height of the season 2013 than those of the season 2012 could be due relatively higher temperature (on the average) and relatively lower humidity (on the average) of the year 2013 as compared to 2012 ( Fig 1-8) uptake.

As shown in Fig 9, calculating the relative increase of plant height, as the mean value (Table 3) with reference to the $\mathrm{I}_{1} \mathrm{~N}_{0}$ treatment ( $\mathrm{RF} \mathrm{N}_{0}$ : the rainfall +0 $\mathrm{kg} \mathrm{N} \mathrm{ha}{ }^{-1}$, i.e., the control treatment ). The highest value of relative increase was obtained as a result of $\mathrm{I}_{2} \mathrm{~N}_{1}$ (treatment No. 5; SDI $\mathrm{N}_{90}$ : surface drip irrigation + $90 \mathrm{~kg} \mathrm{~N} \mathrm{ha}^{-1}$ ) and the lowest value was obtained as a result of $\mathrm{I}_{1} \mathrm{~N}_{1}$ (treatment No. 2; RF $\mathrm{N}_{90}$ : the rainfall +90 $\left.\mathrm{kg} \mathrm{N} \mathrm{ha}{ }^{-1}\right)$. nitrogen rates. As shown in Table 3 the highest mean (SDI, SSDI) could be mainly due to high availability of 


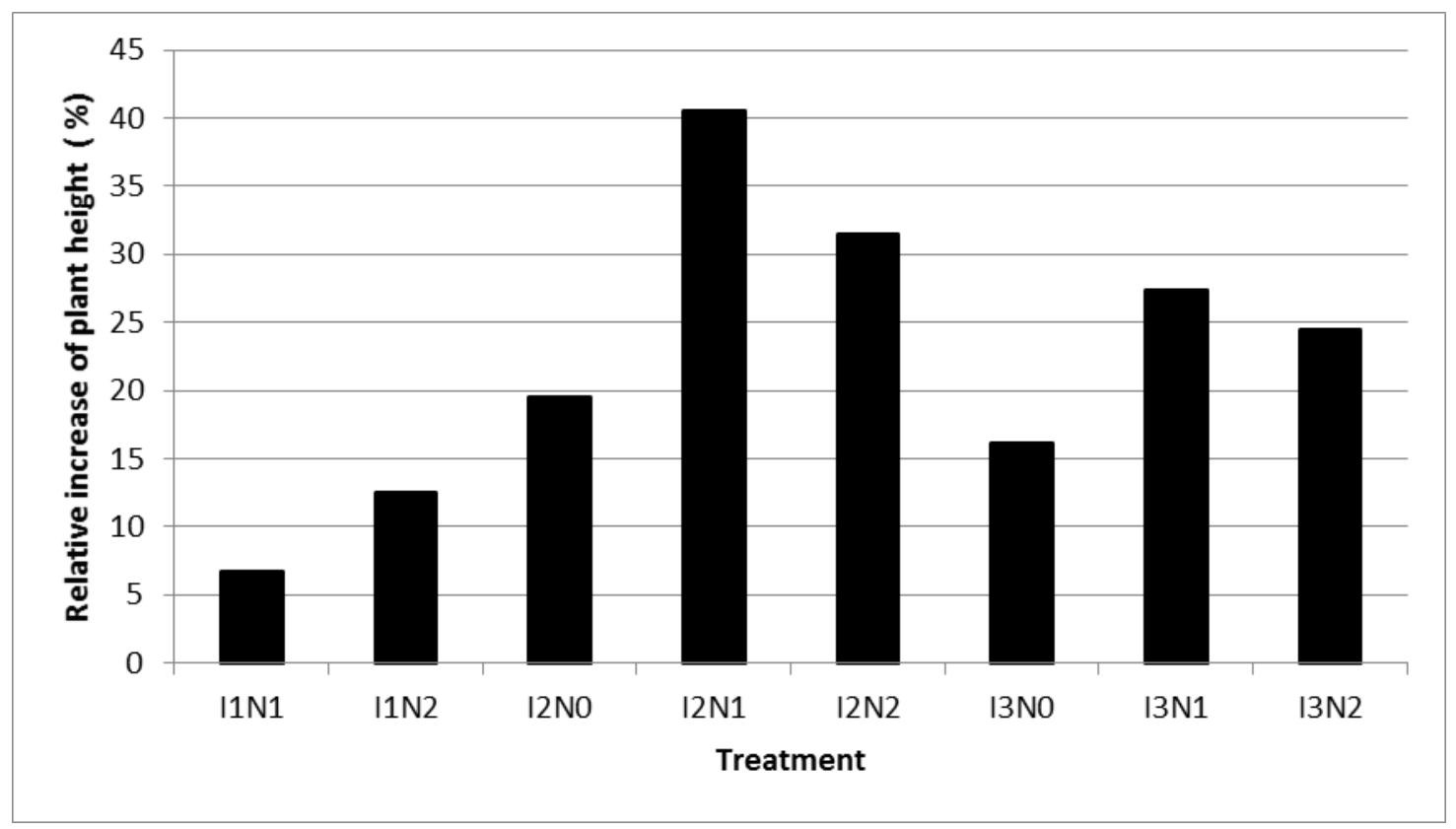

Fig. 9. The relation between application of irrigation method and nitrogen fertilizer rate on the mean value of relative increase of plant height as reference to $\left(I_{1} N_{0}\right)$ treatment

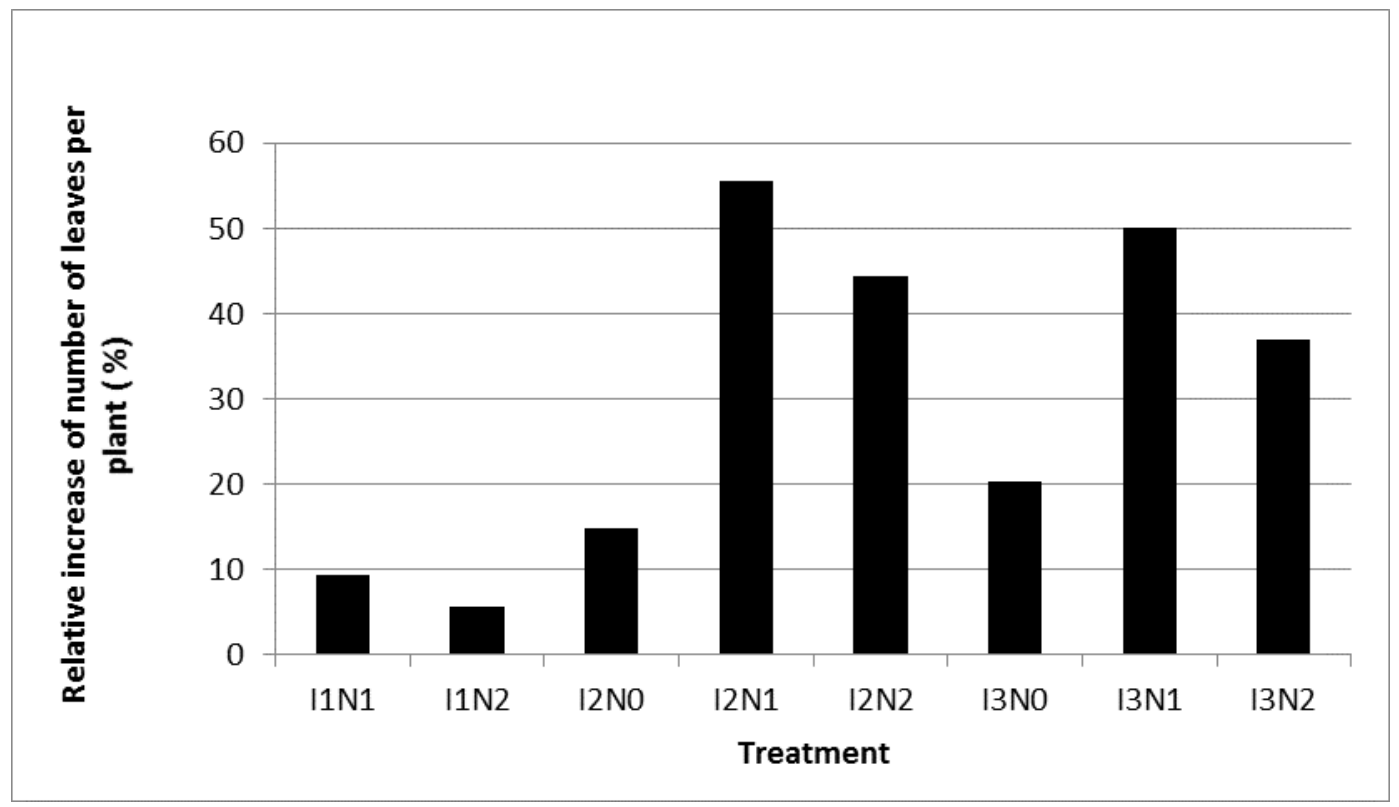

Fig. 10. The relation between application of irrigation method and nitrogen fertilizer rate on the mean value of relative increase of number of leaves per plant as reference to $\left(I_{1} N_{0}\right)$ treatment

It has been reported that the increasing plant height with using SDI and SSDI also indicate the favorable effect of water in maintaining the turgor pressure of the cell which is the major prerequisite for plant growth (Vaux and Pruit,1983). On the other hand, the decrease of plant height under soil moisture stress (especially when not using the irrigation method ; RF) may be due to stomata closure and reduced $\mathrm{CO}_{2}$ and nutrient uptake by the plants and, hence, photosynthesis and other biochemical process are hampered (El- Noemani et al., 2009).

The obtained results are also in agreement with the data reported by Al-Moshileh (2007) who found that with increasing soil water supply, plant growth parameters (plant height) were significantly increased. Similarly, Biswas et al. (2003) stated that onion bulbs of 
irrigated treatments were bigger whereas plants grown without supplemental irrigation were significantly smaller. Kumar et al.(2007a) also observed that irrigation had positive significant effect on plant height; which subsequently influenced the crop yield.

\section{2- Numer of leaves per plant}

Table 3 showed that the number of leaves per plant was significantly $(\mathrm{P}<0.05)$ affected by both irrigation methods and application rates of nitrogen fertilizer. Based on the obtained results, the highest number of leaves (8.4 leaves per plant) was recorded due to both surface drip irrigation (SDI) and fertilization with $90 \mathrm{~N}$ $\mathrm{kg} \mathrm{ha}^{-1}\left(\mathrm{I}_{2} \mathrm{~N}_{1}\right)$ while the least number (5 leaves per plant) was recorded with the unfertilized with nitrogen and the non-irrigation $\left(\mathrm{I}_{1} \mathrm{~N}_{0}\right)$ treatment; i.e. depending on rainfall $\left(\mathrm{RF}+0 \mathrm{~kg} \mathrm{~N} \mathrm{ha}{ }^{-1}\right)$.

The number of leaves per plant was significantly improved with $\mathrm{I}_{2} \mathrm{~N}_{1}$, surface drip irrigation (SDI) and fertilization with $180 \mathrm{~kg} \mathrm{~N}$ ha $^{-1}\left(\mathrm{I}_{2} \mathrm{~N}_{2}\right)$, subsurface drip irrigation (SSDI) and fertilization with $90 \mathrm{~kg} \mathrm{~N} \mathrm{ha}^{-1}($ $\mathrm{I}_{3} \mathrm{~N}_{1}$ ) and subsurface drip irrigation (SDI) and fertilization with $180 \mathrm{~kg} \mathrm{~N}^{-1}\left(\mathrm{I}_{3} \mathrm{~N}_{2}\right)$ as compared to other treatments $\mathrm{I}_{1} \mathrm{~N}_{0}, \mathrm{I}_{1} \mathrm{~N}_{1}, \mathrm{I}_{1} \mathrm{~N}_{2}, \mathrm{I}_{2} \mathrm{~N}_{0}$ and $\mathrm{I}_{3} \mathrm{~N}_{0}$. It is clear, therefore, that onion plant leaf formation had responded to nitrogen fertilization with high availability of soil moisture.

As shown in Fig 10, calculating the relative increase of number of leaves per plant as mean value (Table 3 ) with reference to the $I_{1} N_{0}\left(R F N_{0}\right.$ :the rainfall $+0 \mathrm{~kg} \mathrm{~N}$ $\mathrm{ha}^{-1}$; i.e. the control treatment ), the highest value of relative increase was obtained as a result of $\mathrm{I}_{2} \mathrm{~N}_{1}$ (treatment No. 5; SDI $\mathrm{N}_{90}$ : surface drip irrigation +90 $\mathrm{kg} \mathrm{N} \mathrm{ha}{ }^{-1}$ ) and the lowest value was a result of $\mathrm{I}_{1} \mathrm{~N}_{2}$ treatment $\left(\mathrm{RF} \mathrm{N}_{180}\right)$.

Biswas et al. (2003) showed irrigated onion bulbs produced the highest leaves number per plant than the non-irrigated one, whereas onion grown without supplemental irrigation gave the lower number of leaves. This indicated that as plants respond to water stress by closing their stomata to slow down water loss through transpiration, the gas exchange within the leaf is limited, consequently, photosynthesis processes and plant growth will slow down (Curah and Proctor, 1990). The obtained results agree also with the findings of Wien (1997) who reported that the number of leaves had a linear relation with the availability of soil moisture.

\section{3- Bulb dry matter}

Table 3 showed that bulb dry matter of onion plant was significantly affected $(\mathrm{P}<0.05)$ by both irrigation methods and application rate of nitrogen fertilizer. The percentages bulb dry matter were 12.6, 13.4, 12.8, 13.2, $14.8,14.2,13.5,14.5$ and 13.9 due to treatments: $\mathrm{I}_{1} \mathrm{~N}_{0}$,
$\mathrm{I}_{1} \mathrm{~N}_{1}, \mathrm{I}_{1} \mathrm{~N}_{2}, \mathrm{I}_{2} \mathrm{~N}_{0}, \mathrm{I}_{2} \mathrm{~N}_{1}, \mathrm{I}_{2} \mathrm{~N}_{2}, \mathrm{I}_{3} \mathrm{~N}_{0}, \mathrm{I}_{3} \mathrm{~N}_{1}$ and $\mathrm{I}_{3} \mathrm{~N}_{2}$, respectively for growing season 2012 and 12.4, 13.2, $12.6,13.1,14.5,14.3,13.3,14.6$ and 14.2 due to treatments : $\mathrm{I}_{1} \mathrm{~N}_{0}, \mathrm{I}_{1} \mathrm{~N}_{1}, \mathrm{I}_{1} \mathrm{~N}_{2}, \mathrm{I}_{2} \mathrm{~N}_{0}, \mathrm{I}_{2} \mathrm{~N}_{1}, \mathrm{I}_{2} \mathrm{~N}_{2}, \mathrm{I}_{3} \mathrm{~N}_{0}, \mathrm{I}_{3} \mathrm{~N}_{1}$ and $\mathrm{I}_{3} \mathrm{~N}_{2}$, respectively for growing season 2013 .

The results showed that increasing the dry matter content of onion bulbs was recorded with $\mathrm{I}_{2} \mathrm{~N}_{1}$ treatment as compared to dry matter content of onion bulbs recorded with $\left(\mathrm{I}_{1} \mathrm{~N}_{0}\right)$ treatment.

Fig. 11 showed that the highest value of relative increase of bulb dry matter was obtained as a result of $\mathrm{I}_{2} \mathrm{~N}_{1}$ (SDI $\mathrm{N}_{90}$ : surface drip irrigation $+90 \mathrm{~kg} \mathrm{Nha}^{-1}$; i.e. treatment No. 5) treatment; and the lowest values was due to $\mathrm{I}_{1} \mathrm{~N}_{2}\left(\mathrm{RF} \mathrm{N}_{180}\right)$ treatment.

In agreement with the obtained results, Al-Kaisi and Broner (2005) reported that water stress at any growth stage of onion led to reduction of dry matter yield, which could possibly be due to limitation in assimilate production and accumulation in bulbs under stress conditions. Kebede (2003) found that moisture stress had no significant effect on bulb dry matter content of shallot, but it tended to be high in plants stressed at the late stage of growth. Patricia and Bansal (1999) also reported that nitrogen application had no effect on potato tuber dry matter.

\section{4-Bulb diameter}

Table 3 showed that nitrogen fertilization and supplementary irrigation significantly $(\mathrm{P}<0.05)$ increased the bulb diameter of onion. In response to increasing the rate of nitrogen fertilizer from nil to 90 and $180 \mathrm{~kg} \mathrm{~N} \mathrm{ha}^{-1}$, the bulb diameter significantly increased linearly. The mean bulb highest diameter (5.3 $\mathrm{cm}$ ) was recorded as a result of $\mathrm{I}_{2} \mathrm{~N}_{2}$ treatment, while the lowest mean bulb diameter $(3.2 \mathrm{~cm})$ was recorded due to treatment by $\mathrm{I}_{1} \mathrm{~N}_{0}$. These results agree with those found by Rehman et al. (1978) due to NPK fertilization and Hassan (1984) as a result of sufficient irrigation and nitrogen application.

Fig. 12 showed that the highest value of relative increase $(65.6 \%)$ of bulb diameter has been obtained as a result of $\mathrm{I}_{2} \mathrm{~N}_{2}$ treatment (surface drip irrigation + $180 \mathrm{~kg} \mathrm{Nha}^{-1}$; i.e. treatment No. 6) and the lowest value of relative increase $(21.9 \%)$ was due to $\mathrm{I}_{1} \mathrm{~N}_{1}$ ( $\mathrm{RF} \mathrm{N}_{90}$ : rainfall $+90 \mathrm{~kg} \mathrm{~N} \mathrm{ha}^{-1}$ ).

\section{5- Average bulb weight}

The obtained results of average bulb weight confirm the same trend in plant height, leaf number of plant, bulb dry matter and bulb diameter (Table 3). Average bulb weight of onion plants was significantly $(\mathrm{P}<0.05)$ affected by the studied irrigation methods and rates of application of nitrogen fertilizer. 


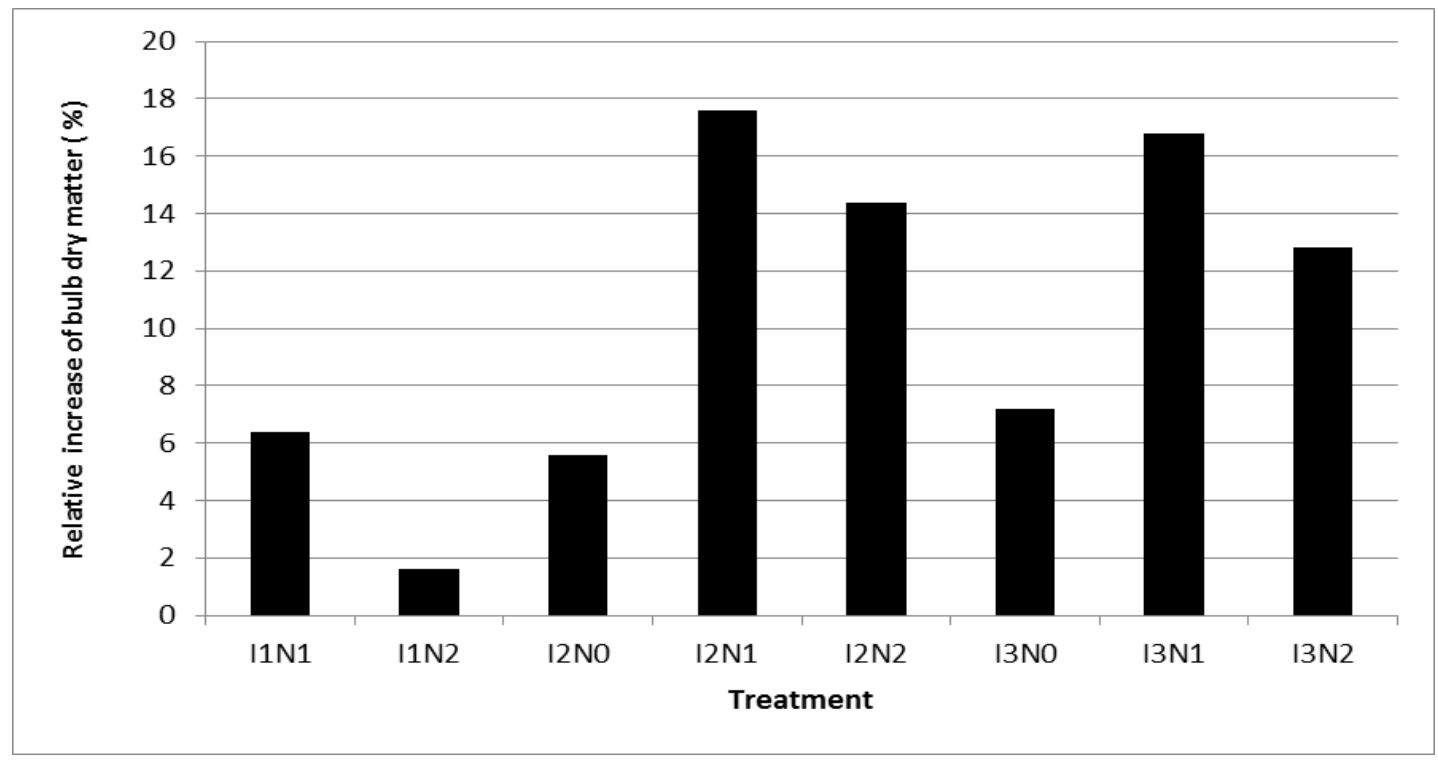

Fig.11. The relation between application of irrigation method and nitrogen fertilizer rate on the mean value of relative increase of bulb dry matter as reference to $\left(I_{1} N_{0}\right)$ treatment

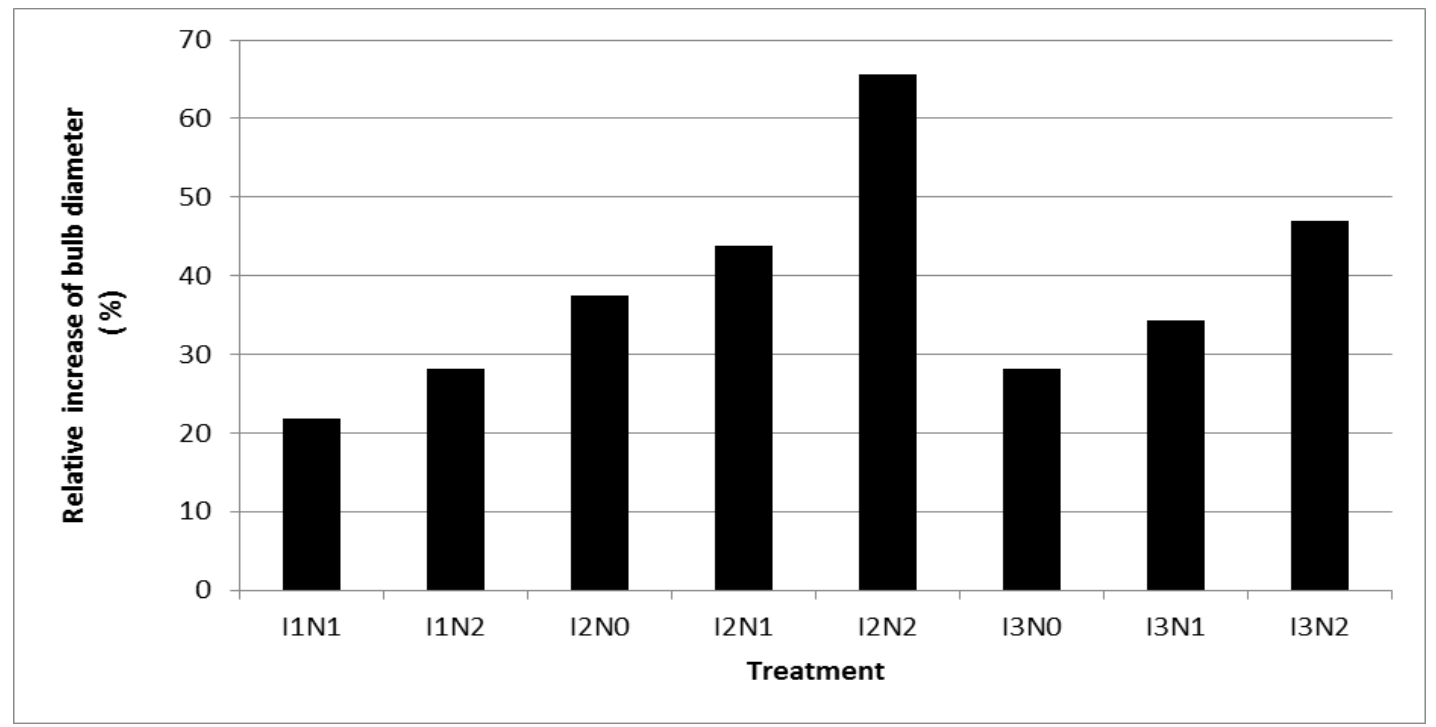

Fig.12. The relation between application of irrigation method and nitrogen fertilizer rate on the mean value of relative increase of bulb diameter as reference to $\left(I_{1} N_{0}\right)$ treatment

Table 3 showed that the average bulb weight were $59.2,64.3,70.2,72.4,84.7,102.4,69.4,84.6$ and $90.5 \mathrm{gm}$ due to the treatments $\mathrm{I}_{1} \mathrm{~N}_{0}, \mathrm{I}_{1} \mathrm{~N}_{1}, \mathrm{I}_{1} \mathrm{~N}_{2}, \mathrm{I}_{2} \mathrm{~N}_{0}$, $\mathrm{I}_{2} \mathrm{~N}_{1}, \mathrm{I}_{2} \mathrm{~N}_{2}, \mathrm{I}_{3} \mathrm{~N}_{0}, \mathrm{I}_{3} \mathrm{~N}_{1}$ and $\mathrm{I}_{3} \mathrm{~N}_{2}$, respectively in the growing season 2012 and were $60.1,65.7,69.5,73.8$, $85.2,101.6,68.3,82.5$ and $90.1 \mathrm{gm}$ due to the treatments $\mathrm{I}_{1} \mathrm{~N}_{0}, \mathrm{I}_{1} \mathrm{~N}_{1}, \mathrm{I}_{1} \mathrm{~N}_{2}, \mathrm{I}_{2} \mathrm{~N}_{0}, \mathrm{I}_{2} \mathrm{~N}_{1}, \mathrm{I}_{2} \mathrm{~N}_{2}, \mathrm{I}_{3} \mathrm{~N}_{0}$, $\mathrm{I}_{3} \mathrm{~N}_{1}$ and $\mathrm{I}_{3} \mathrm{~N}_{2}$, respectively in the growing season 2013

As shown in table 3 the highest mean bulb weight $(102.0 \mathrm{~g})$ was recorded with $\mathrm{I}_{2} \mathrm{~N}_{2}$ treatment, while the lowest mean bulb weight $(59.7 \mathrm{~g}$ ) was obtained with $\mathrm{I}_{1} \mathrm{~N}_{0}$ treatment. Fig. 13 showed the highest value of relative increase $(70.9 \%)$ of average bulb weight was obtained as a result of $\mathrm{I}_{2} \mathrm{~N}_{2}$, while the lowest value was obtained as a result of $\mathrm{I}_{1} \mathrm{~N}_{1}$ treatment.

Increasing bulb weight in response to nitrogen application and using surface and subsurface irrigation (supplementary irrigation) could be attributed to the increase in number of leaves per plant, leaf length, and extended physiological maturity in response to $\mathrm{N}$ fertilization, which may led to increased assimilates 
production and allocations to the bulbs ( Hassan et al., 1984 and Ells et al., 1993) .

Abdulaziz (2003) found that the average bulb weight of onion was significantly increased with relatively high soil moisture content . Hassan (2007) also observed that highest average bulb weight was obtained with $90 \mathrm{~kg} \mathrm{~N}$ $\mathrm{ha}^{-1}$. Nasreen et al. (2007) reported that high nitrogen application rate increased the bulb weight of onion.

\section{3-Yield, Evapotranspiration of Onion and Water Use Efficiency}

As shown in Table 4, the number of irrigations events varied from 5 to 6 for the two growing seasons: 2012 and 2013, respectively. It is clear that the rainfall treatments consumed less water than drip- irrigation treatments and subsurface drip - irrigation treatments, which recorded a range from 386.6 to $388.3 \mathrm{~mm}$, from 427.5 to $430.7 \mathrm{~mm}$ and from 452.2 to $448.2 \mathrm{~mm}$, respectively for the growing season 2012 and from 360.4 to $363.2 \mathrm{~mm}$, from 419.2 to $413.1 \mathrm{~mm}$ and from 438.5 to $438.3 \mathrm{~mm}$, respectively in the growing season 2013. Irrigation and rain fed ET values ranged from 413.2 to $452.2 \mathrm{~mm}$ and from 360.4 to $386.6 \mathrm{~mm}$, respectively.

The yield of onion (Table 4 and Fig. 14) was higher with drip-irrigation treatments and subsurface drip-irrigation treatments which recorded within 29.8 38.0 t.ha $^{-1}$ and $26.3-34.8$ t.ha $^{-1}$ respectively in the growing season 2012 and within 30.5 - 39.2 t.ha $^{-1}$ and $27.1-35.2$ t.ha $^{-1}$, respectively in the growing season 2013 .

The lowest onion yield was obtained under rain fed conditions, which recorded from 20.47 to 23.9 t.ha $^{-1}$ and from 21.2 to 23.1 t.ha $^{-1}$, in the growing season 2012 and 2013, respectively. The highest yield of onion bulbs (39.2 t. ha ${ }^{-1}$ ) was produced with treatment $\mathrm{I}_{2} \mathrm{~N}_{1}$ ( SDI $\mathrm{N}_{90}$ : surface drip irrigation $+90 \mathrm{~kg} \mathrm{~N} \mathrm{ha}^{-1}$ ) in 2013 .

Doorenbos and Kassam (1986) found that onion yields within 35 - $45 \mathrm{t} \mathrm{ha}^{-1}$ could be obtained with 350 - $550 \mathrm{~mm}$ water using furrow irrigation. The obtained results are in agreement with those obtained by Halim and Ener (2001) who recorded seasonal ET of onion under irrigated conditions varied from 394 to $438 \mathrm{~mm}$ and from 177 to $266 \mathrm{~mm}$ in conditions without irrigation for a yield within a range of $35.8-43.1$ and 13.9 - $17.4 \mathrm{t} \mathrm{ha}^{-1}$, respectively, under arid climatic conditions in Turkey. Kadayifci et al. (2005) found that seasonal ET of onion in Turkey ranged from 350 to 450 $\mathrm{mm}$ for bulb yield of $40 \mathrm{tha}^{-1}$.

Data on water use efficiency (WUE) for all treatments (Table 4 and Fig. 15) showed that $I_{2} \mathrm{~N}_{1}$ (surface drip irrigation $+90 \mathrm{~kg} \mathrm{~N} \cdot \mathrm{ha}^{-1}$ ) treatment produced higher WUE as compared to the other studied

Table 4. The values of yield, evapotranspiration of onion and water use efficiency of plants grown in the two growing seasons 2012 and 2013 onion bulb

\begin{tabular}{|c|c|c|c|c|c|c|c|c|c|c|}
\hline $\begin{array}{l}\text { Growing } \\
\text { season }\end{array}$ & Treatment & $\begin{array}{l}\text { Precipitation } \\
\text { (mm) }\end{array}$ & $\begin{array}{c}\text { Drainage } \\
(\mathbf{m m})\end{array}$ & $\begin{array}{l} \pm \Delta \mathbf{S} \\
(\mathbf{m m})\end{array}$ & $\begin{array}{l}\text { Irrigation } \\
(\mathbf{m m})\end{array}$ & $\begin{array}{c}\text { Number } \\
\text { of } \\
\text { Irrigation }\end{array}$ & $\begin{array}{l}\mathbf{E T} \mathbf{T}_{\mathrm{m}} \\
(\mathrm{mm})\end{array}$ & $\begin{array}{l}\mathbf{E T} \mathbf{T}_{\mathbf{a}} \\
(\mathrm{mm})\end{array}$ & $\begin{array}{c}\begin{array}{c}\text { Yield } \\
(\mathrm{t} . \\
\left.\mathrm{ha}^{-1}\right)\end{array} \\
\end{array}$ & $\begin{array}{c}\text { WUE } \\
(\text { kg. ha-1 } \\
\text { mm) } \\
\end{array}$ \\
\hline \multirow[t]{9}{*}{2012} & $\mathrm{I}_{1} \mathrm{~N}_{0}$ & 365.5 & nil & 22.8 & - & - & - & 388.3 & 20.5 & 52.71 \\
\hline & $\mathrm{I}_{1} \mathrm{~N}_{1}$ & 365.5 & nil & 21.2 & - & - & - & 386.7 & 23.3 & 60.25 \\
\hline & $\mathrm{I}_{1} \mathrm{~N}_{2}$ & 365.5 & nil & 20.8 & - & - & - & 386.3 & 23.9 & 61.86 \\
\hline & $\mathrm{I}_{2} \mathrm{~N}_{0}$ & 365.5 & nil & 15.2 & 50.0 & 5 & 430.7 & - & 29.8 & 69.19 \\
\hline & $\mathrm{I}_{2} \mathrm{~N}_{1}$ & 365.5 & nil & 16.3 & 49.3 & 5 & 431.1 & - & 38.0 & 88.24 \\
\hline & $\mathrm{I}_{2} \mathrm{~N}_{2}$ & 365.5 & nil & 13.5 & 48.5 & 5 & 427.5 & - & 32.2 & 75.35 \\
\hline & $\mathrm{I}_{3} \mathrm{~N}_{0}$ & 365.5 & nil & 21.2 & 61.5 & 5 & 448.2 & - & 26.3 & 58.72 \\
\hline & $\mathrm{I}_{3} \mathrm{~N}_{1}$ & 365.5 & nil & 25.5 & 59.5 & 5 & 450.5 & - & 34.8 & 77.25 \\
\hline & $\mathrm{I}_{3} \mathrm{~N}_{2}$ & 365.5 & nil & 23.5 & 63.2 & 5 & 452.2 & - & 29.2 & 64.19 \\
\hline \multirow[t]{9}{*}{2013} & $\mathrm{I}_{1} \mathrm{~N}_{0}$ & 340.0 & nil & 20.4 & - & - & - & 360.4 & 21.2 & 58.82 \\
\hline & $\mathrm{I}_{1} \mathrm{~N}_{1}$ & 340.0 & nil & 21.2 & - & - & - & 361.2 & 22.1 & 61.18 \\
\hline & $\mathrm{I}_{1} \mathrm{~N}_{2}$ & 340.0 & nil & 23.1 & - & - & - & 363.1 & 23.1 & 63.62 \\
\hline & $\mathrm{I}_{2} \mathrm{~N}_{0}$ & 340.0 & nil & 16.7 & 56.4 & 6 & 413.1 & - & 30.5 & 73.83 \\
\hline & $\mathrm{I}_{2} \mathrm{~N}_{1}$ & 340.0 & nil & 18.3 & 61.2 & 6 & 419.5 & - & 39.2 & 93.44 \\
\hline & $\mathrm{I}_{2} \mathrm{~N}_{2}$ & 340.0 & nil & 17.0 & 62.2 & 6 & 419.2 & - & 32.1 & 76.57 \\
\hline & $\mathrm{I}_{3} \mathrm{~N}_{0}$ & 340.0 & nil & 27.1 & 71.2 & 6 & 438.3 & - & 27.1 & 61.83 \\
\hline & $\mathrm{I}_{3} \mathrm{~N}_{1}$ & 340.0 & nil & 25.2 & 67.2 & 6 & 432.4 & - & 35.2 & 81.41 \\
\hline & $\mathrm{I}_{3} \mathrm{~N}_{2}$ & 340.0 & nil & 28.3 & 70.2 & 6 & 438.5 & - & 28.8 & 65.68 \\
\hline
\end{tabular}




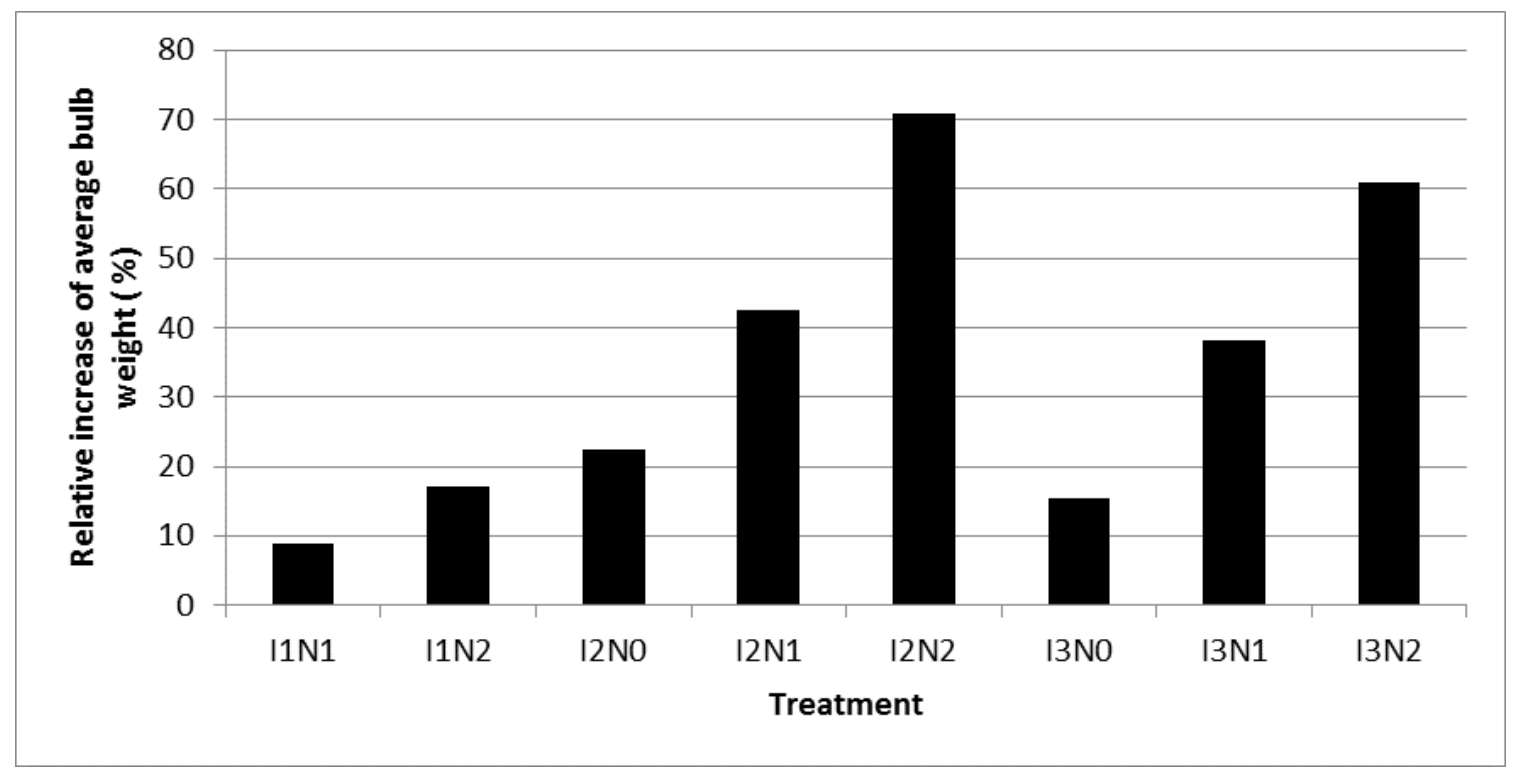

Fig.13. The relation between application of irrigation method and nitrogen fertilizer rate on the mean value of relative increase of average bulb weight as reference to $\left(I_{1} N_{0}\right)$ treatment

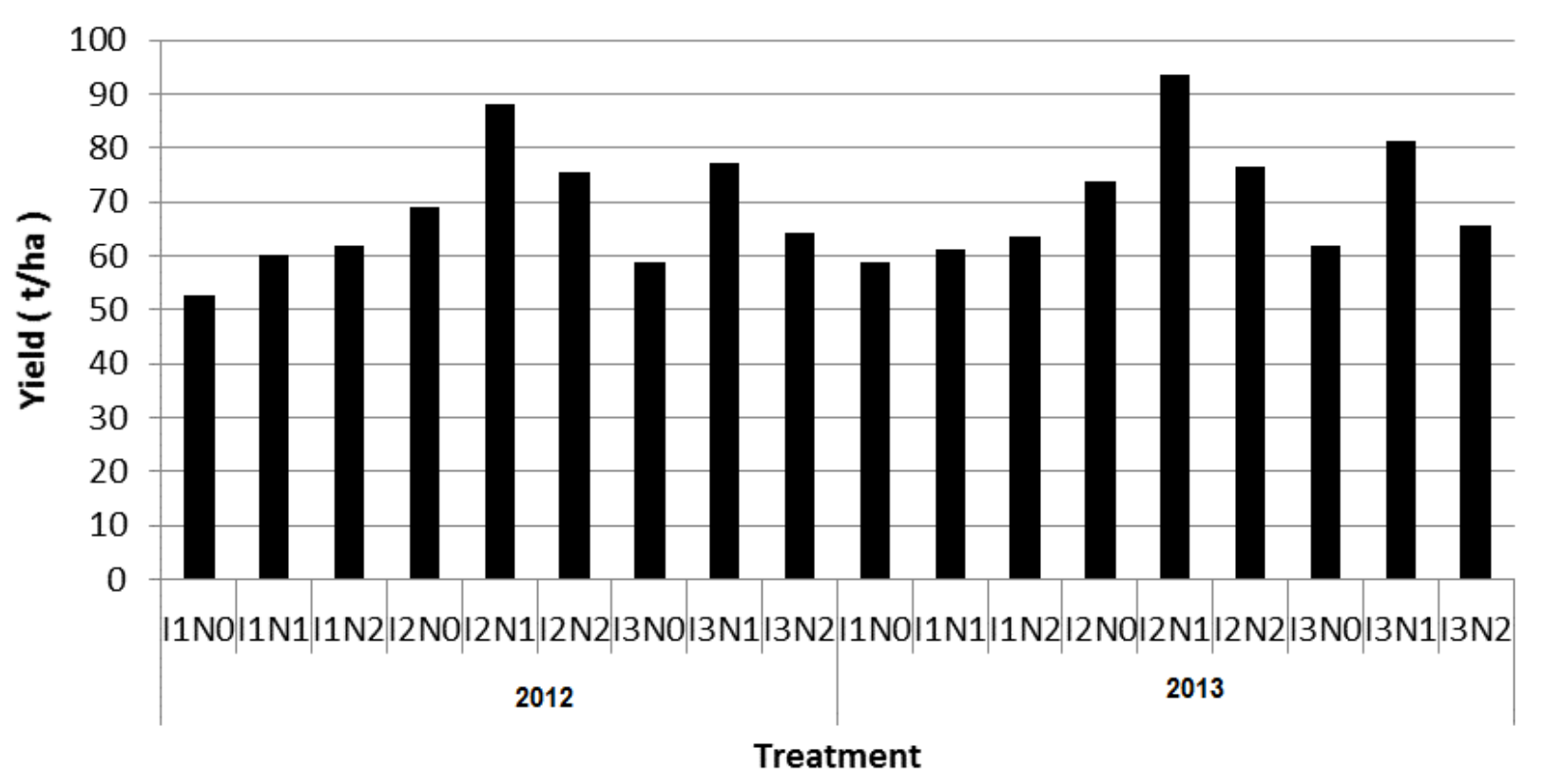

Fig.14.Effect of irrigation methods and nitrogen application on onion yield ( $t$. ha $\left.{ }^{-1}\right)$ under two growing seasons 2012 and 2013

treatments in both the two growth seasons 2012 and 2013 .The water use efficiency (WUE) of all treatments ranged from 52.71 to $93.44 \mathrm{~kg} \cdot \mathrm{ha}^{-1} \mathrm{~mm}$. These results are in agreement with the statement that crop yield depends on the quantity of water use, and that all factors increasing yield and decreasing water used for ET favorably affected WUE (Arnon, 1975).

The obtained results (Table 4) showed that the highest yield obtained in 201238.0 t.ha $^{-1}$ was the result of $\mathrm{I}_{2} \mathrm{~N}_{1}$ and associated with the highest WUE ( $88.24 \mathrm{~kg}$. $\mathrm{ha}^{-1} \mathrm{~mm}$ ) . This is also found for onion yield in 2013 where the highest yield ( 39.2 t.ha $^{-1}$ ) was the result of $\mathrm{I}_{2} \mathrm{~N}_{1}$ and associated with the highest WUE $(93.44 \mathrm{~kg}$. ha${ }^{1} \mathrm{~mm}$ ). The occurrence of higher values of onion yield and WUE in the growing season 2013 than in that of 2012 may be attributed relatively higher temperature and relatively lower humidity in 2013 than in 2012. 


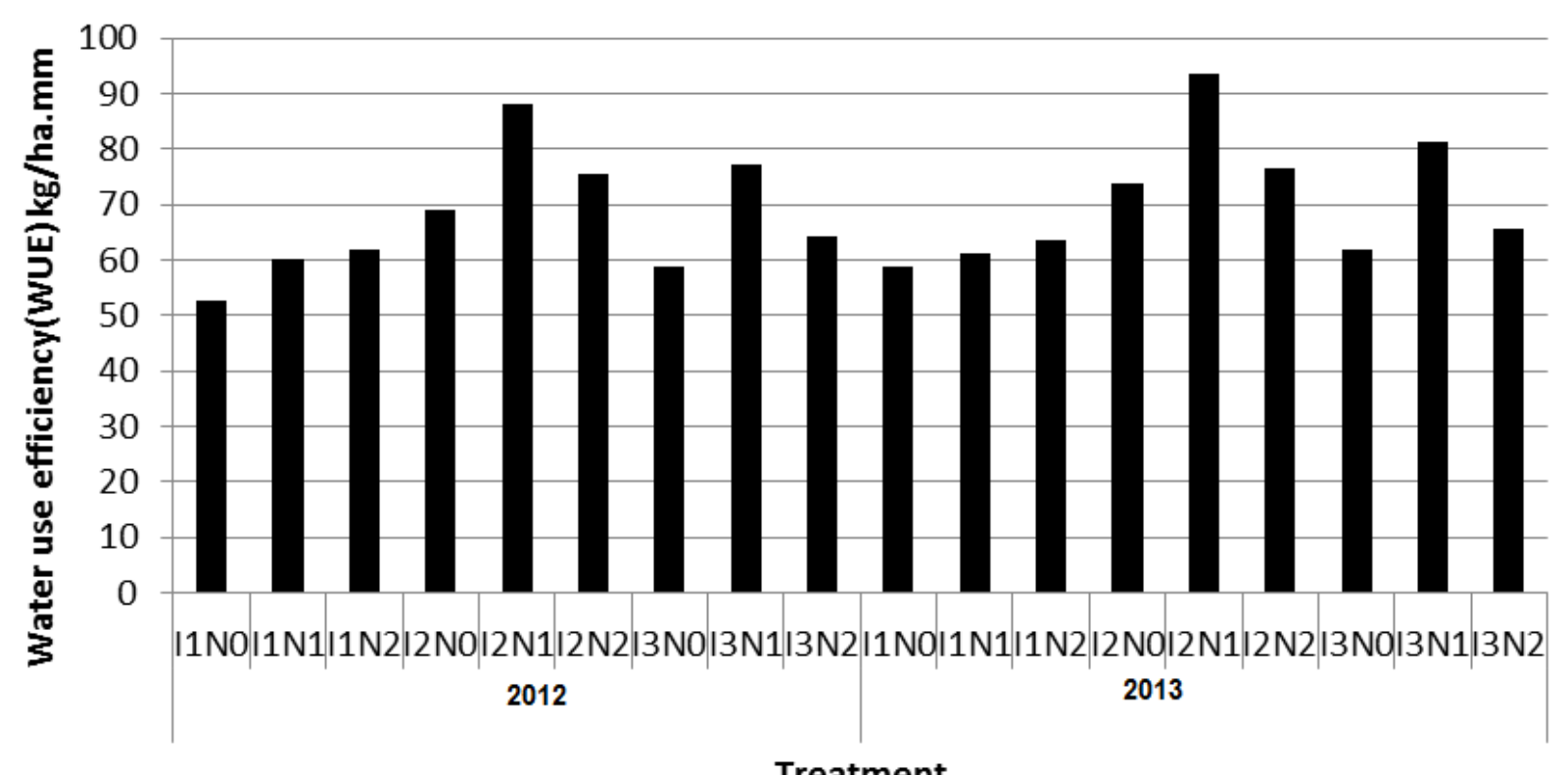

Treatment

Fig. 15. Effect of irrigation methods and nitrogen application on water use efficiency $\left(\mathrm{kg} \cdot \mathrm{ha}^{-1} \cdot \mathrm{mm}\right)$ of onion grown in two growing seasons 2012 and 2013

\section{CONCLUSION}

The Results obtained in this study indicated that surface drip irrigation, subsurface drip irrigation in combination with $90 \mathrm{~kg} \mathrm{~N} / \mathrm{ha}$ produced higher yield and yield components of onion. The highest values of plant height, number of leaves/plant, and neck diameter were obtained by SDI $+90 \mathrm{~kg} \mathrm{~N} / \mathrm{ha}$ treatment while the lowest values belonged to RF treatment with zero (0.0) level of applied Nitrogen. The fresh crop yield was the highest with SDI $+90 \mathrm{~kg} \mathrm{~N} / \mathrm{ha}$ treatment, while RF treatment with 0.0 nitrogen produced the lowest value of crop yields. The highest WUE was obtained by the SDI $+90 \mathrm{~kg} \mathrm{~N} \cdot \mathrm{ha}^{-1}$ treatment while the lowest value of WUE was obtained through RF treatment with 0.0 nitrogen. It is clear, therefore, that SDI $+90 \mathrm{~kg} \mathrm{~N} \cdot \mathrm{ha}^{-1}$ treatment can be considered the most effective irrigation method with moderate Nitrogen application in improving WUE and increasing yield and yield components of onion grown under environmental Russian conditions.

\section{REFERENCES}

Abdulaziz, R. Al-Harbi. 2003. Effect of irrigation regimes on growth and yield of onion (Allium cepa L.). http://digital.library.ksu.edu.sa/paper315.html.Accessed date 30/7/2008 .

Arnon, I. 1975. Physiological aspects of dryland farming. Ed: U.S. Gupta, Haryana Agricultural University Hissar.
Al- Moshileh, A. 2007. Effects of planting date and irrigation water level on onion (Allium cepa L.) production under central Saudi Arabian conditions. Basic Applied Sci. 8(1): 14-28.

Al-Kaisi, M.M. and I. Broner. 2005. Crop water use and growth stages. Colorado State University, cooperative extension- agriculture. 4715: 1- 8.

Ayers, J.E., Phene, C.J., Hutmacher, R.B., Davis, K.R., Shoneman, R.A., Vail, S.S., Mead, R.M. 1999 Subsurface drip irrigation of row crops: a review of 15 years of research at The Water Management Laboratory. Agric Water Manage. 42(1):1-27.

Biswas, S.K., P.K. Sarker, A. K. M, Mazharulislam, M.A. Bhuyan and B.C. Kundu. 2003. Effect of irrigation on onion production. Pakistan J. Biol. Sci. 6(20): 1725-1728.

Currah, L. and F.J. Proctor. 1990. Onion in Tropical Regions. Natural Resources institute. Chatham Maritime, kent, UK. p. 232 .

Doorenbos, J., Kassam, A.H. 1986. Yield Response to Water. Irrigation and Drainage Paper No. 33, FAO, Rome, Italy. p. 144.

Ells, J.E., A.E. McSay, P.N. Soltanpour, F.C. Schweissing, M.E. Bartolo, and E.G. Kruse. 1993. Onion irrigation and nitrogen leaching in the Arkansas Valley of Colorado, 1990-1991. Hort Technol. 3:184-187.

El-Noemani, A. A., A.A.A. Aboamera, O.M. Aboellil and Dewedar. 2009. Growth, yield, quality and water use efficiency of pea plant as affected by evapotranspiration and sprinkler height. J. Agri. Res. 34: 1445-1466. 
Halim, O.A., M. Ener. 2001. A study on irrigation scheduling of onion (Allium cepa L.) in Turkey. J. Biol. Sci. 1(8): 735-736.

Halvorson, A.D., M. Bartolo, C.A. Reule and A.Berrada. 2008. Nitrogen effect on onion yield under drip and furrow irrigation . Agron. J. $100: 1062-1069$

Hassan, M.S., 1984. Effect of frequency of irigation and nitrogen fertilizer on yield and quality of onions (Affium cepa L.) in the arid tropics, Acta. Hort. 143: 341-346.

Hassen, M.S. 2007. Effects of frequency of irrigation and fertilizer nitrogen on yield and quality of onions in the arid tropics. http://www.actahort.org. books 143: 143-38.htm.

Kadayifci, A., Y. Tuylu GI, Ucar, B. Cakmak. 2005. Crop warer use of onion (Allium cepa L.) in Turky. Agric. Water Manage. 72: 59-68.

Kebede Woldetsadik. 2003. Shallot (Allium cepa var. ascalonicum) responses to plant nutrient and soil moisture in a sub- humid tropical climate. J. Horticultural sci. Biotechnol. 78(4):549-555.

Kumar, S., Imtiyaz, M., Kumar, A., R.Singh. 2007a. Response of onion (Allium cepa L.) to different levels of irrigation water. Agricultural Water Management. 88: 161-166.

Longo Dominic, F., D. Thomos Spears. 2003 Water scarcity and modern irrigation. Valmont-Water Management Groups, Valmont Water Management Group 7002 North 288 Street PO. Box 358, Valley, NE 68064-0358 USA, 16 p. (available online http://www.valmont. com/asp/irrigation/pdf/ValmontWaterScarcity.pdf)

Nasreen, M. M. Haque, M. A. Hossain and A. T. M. Farid. 2007. Nutrient uptake and yield of onion as influenced by nitrogen and sulphur fertilization. Bangladesh J. Agri. Res. 32(3): 413-420.

Neelam P. and T.B.S.Rajput. 2009 Effect of subsurface drip irrigation on onion yield, Irrig Sci. 27:97-108

Ollala, F.S., A.D. Padilla and R.Lopex. 2004. Production and quality of the onion crop (Allium cepa L.) cultivated under controlled deficit irrigation conditions in a semi-arid climate. Agric. Water Manage. 68: 77-89.
Patricia, I. and S. K. Bansal. 1999 Potassium and integrated nutrient management in potato. A paper presented at the Global Conference on Potato. New Delhi, India.

Rehman, S., M.R. Talukdur and A.M. Mian. 1978. Effect of NPK on the bulb size and yield of onion. Vegetable Crops. In. Horticulture. Eds Elena Bashir and Robyn Bantel. National Book Foundation. Islamabad. Pakistan. Pp. 501.

Sammis, T.W., M.S. Al-Jammal, S. Ball and D. Smeal. 2000. Crop water use of onion. In: Proceedings of sixth International Micro Irrigation Congress, Micro 2000, Cape Town, South Africa. 1-9.

Shamima, N. and A.K.M. Hossain. 2000. Influence of chemical fertilizers and organic manure on the growth and yield of onion. Bangladesh J. Agric., Res. 25(2): 221-231.

Singh, D.K., T.B.S. Rajput, H.S. Sikarwar, R.N. Sahoo, T. Ahmed. 2006 Simulation of soil wetting pattern with subsurface drip irrigation from line source. Agric. Water Manage. 83:130-134

Strange, M.L. 2005 Newsletter for onions and garlic for Fresno, Tulare and Kings Counties. University of California Cooperative Extension. 4437-B S. Laspina Street, Tulare. CA 93274.

USEPA (US Environmental Protection Agency),1993. Standard for the use and disposal of sewage sludge. Office of Water, EPA-822/ R-96-003. Environmental Protection Agency, Washington D. C.

Vaux, H. J. and W.O. Pruit. 1983. Crop water production function. In: D. Hillel (Ed). Advance irrigation. 12:16-93. Wien H. 1997. Physiology of vegetable crops. In: J.L. Brewster (Ed.). Onions and Garlic, Cambridge University Press, New York. pp.581-612.

Wien, H. 1997. Physiology of vegetable crops. In: J.L. Brewster (Ed.). Onions and Garlic, Cambridge University Press, New York. pp.581-612.

Živkovic, B., V. Nejgebauer, D.j. Tanasijevic, N. Miljkovic, L. Stojkovic, P. Drezgic. 1972. Soils of Vojvodina, Ed. Faculty Agric. Novi Sad Serbia (In Serbian). 


\section{الملخص العربي}

\section{تاثير طرق الرى وإضافة النتروجين على محصول البصل ومكوناتة النامى تحت الظروف البيئية الروسية}

$$
\text { أثرف السيد النماس }
$$

نتيروجينى لكل هكتار بينما سجلت معاملة الرى بالأمطار مع عدم إضافة سماد نتروجينى أقل القيم المتحصل عليها لمكونات المحصول المختلفة. سجلت أعلى كمية محصول

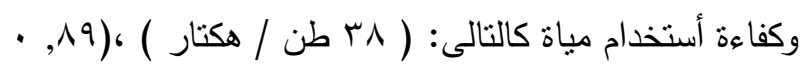
طن / هكتار/سم ) على الترتيب للنباتات المرويه بالتنقيط

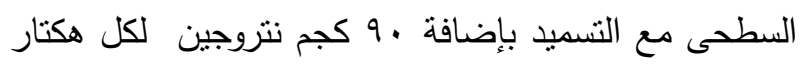

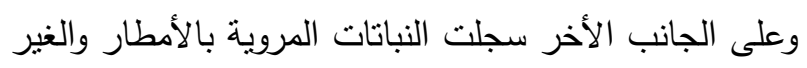
مسمدة تسميدا نتروجينيا أقل كمية للمحصول وكفاءة أستخدام مياة وكانت النتائج كالتالى: 0, • rطن / هكتار و roro, ·طن

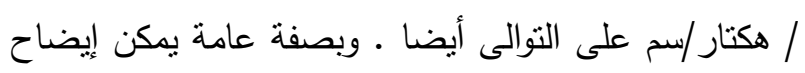

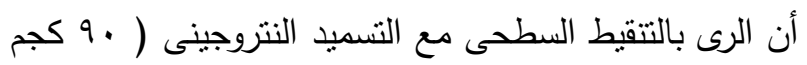
سماد نتيروجين لكل هكتار ) قد أعطى تحسن معنوى لكلا من محصول البصل ومكوناتة وكذلك كفاءة إستخدام المياة للمحصول وذلك تحت الظروف البيئية الروسية لمدينة

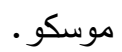

أجريت تجربة حقلية لدراسة تأثير ثثلاث طرق ري ومعدلات التسميد بالنتزوجين على محصول البصل Allium) ومكوناتة تحت الظروف البيئية Cepa L., cv. Creole Red)

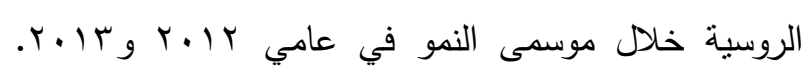
إستخدم ثلاثة طرق رى: فى التجربة هى مياة الامطار والرى هيه

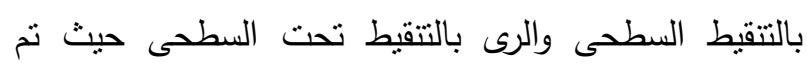

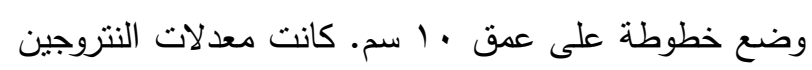

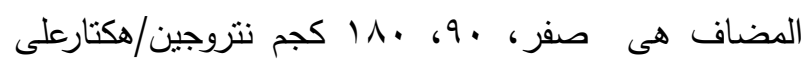
صورة سلفات الأمونيوم وتم تتفيذ التجربة في تصميم القطاعات العشوائية الكاملة بثلاثة مكررات. وقد بينت النتائج المتحصل عليها أن الرى بالتتقيط السطحى وتحت السطحى بله

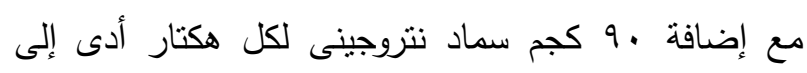
زيادة المحصول ومكوناتة. تم الحصول على أعلى قيم لإرتفاع النباتات وعدد الأوراق لكل نبات وقطر البصلة للنباتات المعاملة بالرى بالتتقيط مع إضافة و و كجم سماد 